\title{
ŹRÓDŁA DO DZIEJÓW DIECEZJI WŁOCŁAWSKIEJ W TEKACH KSIĘDZA PROFESORA STANISLAWA LIBROWSKIEGO
}

Diecezja włocławska należy do jednej z najstarszych w Polsce. Jej dzieje wiążą sięz istnieniem biskupstwa w Kołobrzegu (część pomorska), a następnie w Kruszwicy i Włocławku. Tym, który odsłaniał ciekawą, a zarazem złożoną jej przeszłość, był ks. prof. Stanisław Librowski (1914-2002), wykładowca Wyższego Seminarium Duchownego we Włocławku, profesor Katolickiego Uniwersytetu Lubelskiego, Akademii Teologii Katolickiej w Warszawie, Wyższej Szkoły Humanistyczno-Ekonomicznej we Włocławku, długoletni dyrektor Archiwum Diecezjalnego we Włocławku, założyciel i redaktor czasopisma Archiwa, Biblioteki i Muzea Kościelne (dalej: ABMK), nestor polskich historyków kościelnych, członek kilku towarzystw naukowych ${ }^{1}$.

* Ks. Józef Dębiński - dr historii, współpracownik Instytutu Politologii i Stosunków Międzynarodowych UMK w Toruniu.

${ }^{1}$ Z Włocławkiem ks. Stanisław Librowski był związany od wstąpienia do Niższego Seminarium Duchownego w 1931 r., po którego ukończeniu rozpoczął od 1935 r. studia w Wyższym Seminarium Duchownym, którego jednak nie ukończył z powodu wybuchu II wojny światowej i aresztowaniu przez Niemców 7 XI 1939 r. Po wyzwoleniu z obozu koncentracyjnego w Dachau, przyjął święcenia kapłańskie 29 VII 1945 r. w Paryżu z rąk biskupa Karola Radońskiego. Po powrocie do Polski 29 V 1946 r. został administratorem parafii Zgłowiączka, a następnie aż do 1956 r. administratorem parafii Włocławek-Michelin. Od 1958 r. aż do 1984 r. był wykładowcą w Katolickim Uniwersytecie Lubelskim. Pełniąc funkcje duszpasterskie zajmował się też zasobem archiwalnym, który po wywiezieniu przez Niemców szczęśliwie powrócił do Włocławka. Jako archiwista brał udział w wielu zjazdach, sympozjach i seminariach naukowych. Był współpracownikiem Instytutu Badań Literackich PAN (1959-1965) oraz Sekcji Demografii Historycznej PAN w Warszawie (19641969). Należał do kilku towarzystw naukowych, m.in. do Towarzystwa Naukowego KUL i Lubelskiego Towarzystwa Naukowego, Görres-Gesellschaft zür Pflege der Wissenschaft (Kolonia, Niemcy), The International Biographical Centre (Cambridge, Wielka Brytania), The American Biographical Institute Research Association (USA). W 85 rocznicę jego urodzin, wykładowcy historii Kościoła w Polsce, na swoim dorocznym spotkaniem we Włocławku (8 IV 1999 r.), uczcili pamięć ks. Librowskiego. W imieniu zebranych hołd Jubilatowi złożył jego uczeń, opolski biskup koadiutor, Jan Kopiec; S. Librowski, Kalendarium życia, cierpień, działalności i uznania księdza Stanisław Li- 
Swój dorobek naukowy, obejmujący 182 drukowane opracowania i edycje źródeł, w tym ok. 50 większych pozycji, zestawił w większości w tomach ABMK: 30 (1975), s. 321-347; 47(1983), s. 363-386; 58 (1989), s. 269-549; 59 (1990), s. 405-5992. W latach 1994-2002, w redagowanej i wydawanej przez siebie 18 -tomowej publikacji pt. Inwentarz realny dokumentów Archiwum Diecezjalnego we Włocławku, dokonał opracowania inwentarza realnego dokumentów samoistnych, a także inwentarza dokumentów znajdujących się w kopiariuszach Archiwum Diecezjalnego we Włocławku. ${ }^{3}$ Było to, obok ABMK, nie jedyne pismo, którego był redaktorem. Wcześniej (1949-1955) był redaktorem Kroniki Diecezji Włocławskiej (dalej: KDW), w 1957 r. członkiem redakcji dwumiesięcznika teologicznego Ateneum Kapłańskie (dalej: AK), a w latach 1973-1978 - Roczników Teologiczno Kanonicznych ${ }^{4}$. On też, jako jeden z pierwszych, zwrócił uwagę na znaczenie schematyzmów dla badań historycznych i opublikował ich katalog, który znajduje się w Archiwum Diecezjalnym we Włocławku5. Do wielkich dzieł ks. S. Librowskiego należy zaliczyć repertorium ksiag wizytacji kanonicznych arcybiskupów gnieźnieńskich ${ }^{6}$, czy źródła do dziejów Łowicza ${ }^{7}$. Będąc zwolennikiem gromadzenia akt parafialnych w archiwum diecezjalnym, podjął w latach 19601963, za aprobatą biskupów włocławskich (zwłaszcza biskupa Antoniego Pa-

browskiego, „Archiwa Biblioteki i Muzea Kościelne” (dalej: ABMK), 58 (1989) s. 269-549; 59 (1990) s. 405-599; [ S. Librowski], Bibliografia adnotowana ks. prof. dra hab. Stanistawa Librowskiego (W 60-lecie urodzin i 35-lecie pracy naukowej), ABMK 30 (1975) s. 321-347; W. Kujawski, Ks. prof. Stanisław Librowski archiwista, historyk, redaktor, „Studia Włocławskie” (dalej: SW), 2 (1999) s. 8-11; tenże, Librowski Stanisław (1914-2002), ksiadz, archiwista, wydawca źródet i historyk Kościoła, w: Włocławski Stownik Biograficzny, red. S. Kunikowski, t.1, Włocławek 2004, s.95-97; tenże, Ks. prof. dr hab. Stanisław Librowski, archiwista, historyk, redaktor, w: Kościót w Polsce. Dzieje i kultura, t. 2, red. J. Walkusz, Lublin 2003, s. 137-150.

${ }^{2}$ S. Librowski, Chronologiczna bibliografia adnotowana księdza Stanisława Librowskiego z lat 1939-1983, Lublin 1983; tenże, Bibliografia adnotowana ks. prof. dra hab. Stanistawa Librowskiego (W 60-lecie kalendarium życia, cierpień, działalności i uznania Księdza Stanistawa Librowskiego, ABMK 58 (1989) s. 269-549; 59 (1990) s. 405-599.

${ }^{3}$ S. Librowski, Inwentarz realny dokumentów Archiwum Diecezjalnego we Włocławku (dalej: IADW). Dokumenty samoistne, t. I-VII, Włocławek 1994-1999; tenże, IADW. Dziat II. Dokumenty w kopiariuszach, t. I-XI, Włocławek 1999-2002; W. Kujawski, Librowski Stanisław (1914-2002), ksiadz, archiwista, s.95-97; K. Rulka, Bibliografia opublikowanych prac ks. prof. dra hab. Stanistawa Librowskiego, SW, 2 (1999) s.18-30

${ }^{4}$ Rulka, Bibliografia opublikowanych prac, s. 30

${ }^{5} \mathrm{~S}$. Librowski, Katalog rubrycel i schematyzmów diecezji i zakonów historycznej Polski znajdujących się w księgozbiorze podręcznym Archiwum Diecezjalnego we Włocławku, cz. 1-2, ABMK, 23 (1971) s. 213-310; 24 (1971) s. 5-94; 25 (1972) s. 39-113; 26 (1972) s. 89-197; 27 (1973) s. 57130

${ }^{6}$ S. Librowski, Repertorium akt wizytacji kanonicznych dawnej archidiecezji gnieźnieńskiej, cz.4: Indeks geograficzno-historyczny, z. 1: Indeks do części 1(zasób włoctawski), ABMK, 37 (1978) s. $53-174$

${ }^{7}$ S. Librowski, Wypisy z akt kapituly $w$ Łowiczu do zakrystii, skarbca, biblioteki, archiwum $i$ kancelarii miejscowej kolegiaty $i$ kapituly z lat 1525-1818, ABMK, 52 (1986) s. 257-400; 53 (1986) s. 275-393; 54 (1987) s. 299-404; tenże, Zbiór dokumentów miasta Łowicza ujętych około 1780 roku w punkty, ekscerpty i regesty, ABMK, 55 (1987) s. 303-349. 
włowskiego), akcję przejmowania akt z poszczególnych parafii w diecezji. Tym samym przeprowadził spis zawartości kancelarii parafialnych $\mathrm{w}$ diecezji włocławskiej pod względem ksiag metrykalnych, starodruków i innych materiałów archiwalnych ${ }^{8}$. Dla swoich badań stworzył bogaty warsztat naukowy, a także podręczną bibliotekę w Archiwum Diecezjalnym Posiadał także własną bibliotekę, liczącą ok. 5 tysięcy woluminów. Ponadto zebrał wiele innych materiałów historycznych, które posegregował na odpowiednie działy (tzw. „Teki Librowskiego”); obejmuja 110 tek, a ich spis opublikował w 60 tomie $\mathrm{ABMK}^{9}$. W jego zbiorze jest też znaczny zasób: mikrofilmów, map, planów, rysunków, projektów, wykresów oraz pokaźny zbiór monet i medali (Teka XLV) ${ }^{10}$.

Znaczna część „Tek Librowskiego” poświęcona jest biografii i działalności ks. Stanisława Librowskiego. Autor wiele uwagi poświęcił rodzinie i parafii Krzemieniewice (obecnie archidiecezja częstochowska), w której się urodził. Dokładnie omówił swój życiorys, dokumenty i legitymacje, szkołę, wojnę oraz cierpienia, których doznał będąc w obozach (nie pomija przy tym próby ratowania biskupa Michała Kozala przez Hilarego Bretingera). Na uwagę zasługują też kopie dokumentów i akt, np. metryka urodzenia i chrztu czy akt oddania się w opiekę św. Józefowi w Dachau 22 IV 1945 r. (Teka XXIX) ${ }^{11}$. Przytoczył dowody własnościowe i mieszkaniowe odnoszące się zarówno do parafii Michelin, której był administratorem (1946-1956), jak i nabycia dla siebie w 1974 r. mieszkania spółdzielczego w Lublinie oraz posiadania mieszkań służbowych: we Włocławku (Wyższe Seminarium Duchowne: 1946-1967), w Lublinie (konwikt: 1966-1976) oraz jako lokator w Domu Głównym Zgromadzenia Sióstr Wspólnej Pracy od Niepokalanej Maryi we Włocławku przy ul Orlej od 1967 r. i ponownie od 1993 r. aż do śmierci w Wyższym Seminarium Duchownym przy ul Prymasa Stanisława Karnkowskiego 3 (Teki I-VII) ${ }^{12}$. Przytoczył też, poczynając od 1947 r., swoje donacje książkowe (Teka XXV) ${ }^{13}$ oraz swoje starania o rentę inwalidzką, a następnie o emeryturę (Teka XXVII) ${ }^{14}$. Nie brak też różnej dokumentacji, np. pisma,

${ }^{8} \mathrm{~S}$. Librowski, Rejestracja archiwaliów i starych druków na terenie diecezji włocławskiej $w$ roku 1960, „Sprawozdania z czynności wydawniczej i posiedzeń naukowych oraz kronika Towarzystwa Naukowego Katolickiego Uniwersytetu Lubelskiego", 13 (1963) s. 104-106; tenże, Rejestracja archiwaliów i starych druków na terenie diecezji włocławskiej w latach 1960-1962, ABMK, 5 (1962), s. 347-359; 6 (1963), s. 269-278; [W. Surmacz], Archiwalia w parafiach diecezji włoctawskiej, KDW, 46 (1963), s. 293-297.

${ }^{9} \mathrm{~S}$. Librowski, Inwentarz spuścizny rękopiśmiennej księdza Stanisława Librowskiego (Teki Librowskiego), ABMK, 60 (1991) s.5-562

${ }^{10}$ tamże, s. 349; Instrukcja $w$ sprawie porzqdkowania archiwalnego zasobu kartograficznego, w: Zbiór przepisów archiwalnych. Stan na dzień 30 czerwca 1961 r., red. M. Bielińska, A. Ptaśnikowa, Warszawa 1962, s. 128-145

${ }^{11}$ Librowski, Inwentarz, s. 294-298; tenże, Odezwa do księży byłych więźniów w Dachau, „Homo Dei”, 17 (1947) s. 65; tenże, Pielgrzymka księży b. więźniów Dachau do Kalisza, „Ład Boży”, 4 (1948) $\mathrm{nr} 13 / 14$, s. 11

${ }^{12}$ Librowski, Inwentarz, s.17-42.

${ }^{13}$ Tamże, s.283-284.

${ }^{14}$ Tamże, s.286-291. 
karty pocztowe czy koperty (Teka XXVIII) $)^{15}$. Nie pominął także ofiarowanych przez siebie dla rodzinnej parafii paramentów liturgicznych, np. monstrancji (Teka XXVI) ${ }^{16}$.

Ks. S. Librowski, pełniąc w latach 1949-1956 funkcję administratora parafii Włocławek-Michelin, przechowywał, a zarazem zbierał wszystkie akta dotyczące erygowania tej parafii (1939 r.), zmian przynależności dekanalnej, działek pod cmentarz, kościół i plebanię, księgę dochodów i wydatków, akta wizytacji duszpasterskiej, czyli kolędy, sprawozdania z wizytacji biskupich i dziekańskich, kronikę parafii oraz akta luźne (Teka IX) ${ }^{17}$.

Jako wykładowca Wyższego Seminarium Duchownego we Włocławku związany był z tą uczelnią przez ponad 50 lat. Oprócz wykładów prowadził również seminaria naukowe, wygłaszał referaty, $\mathrm{np}$. $\mathrm{z}$ racji drugiej rocznicy pontyfikatu papieża Jana XXIII, czterystulecia istnienia Włocławskiego Seminarium Duchownego $^{18}$, czy Akademii Kopernikowskiej (18 III 1973 r.). Wielkim jego dziełem była wystawa zorganizowana w 1968 r. z okazji czterechsetlecia seminarium $^{19}$. Ks. S. Librowski budził wśród alumnów zainteresowanie historią diecezji, o czym świadczy ilość napisanych przez nich prac dyplomowych poświęconych tej tematyce (Teka XII) ${ }^{20}$. Swoich studentów uczył m. in. jak prowadzić kronikę parafialną, opracować biografię biskupa, czy napisać monografię diecezji lub parafii (Teki: XXXII-XXXIII) ${ }^{21}$.

W 1958 r. ks. S. Librowski, jako znany już archiwista, został pracownikiem KUL, a w 1959 r. zatrudniono go w charakterze adiunkta, a potem kierownika Katedry Archiwistyki Kościelnej i Nauk Pomocniczych Historii w Katolickim Uniwersytecie Lubelskim. Jako pracownik naukowy brał udział w egzaminach licencjackich (22) napisał wiele recenzji prac magisterskich (35), magisterskich i licencjackich (12), doktorskich (9) oraz prac habilitacyjnych (2). Miał 11 seminarzystów. Uczestniczył w 47 kolokwiach habilitacyjnych. (Teka XIII) 22.

O zatrudnienie ks. S. Librowskiego ubiegała się, oprócz Katolickiego Uniwersytetu Lubelskiego, także Akademia Teologii Katolickiej w Warszawie, która powierzyła mu w 1962 r. adiunkturę. Funkcję wykładowcy na tej uczelni pełnił do 1984 r.(Teka XVII) ${ }^{23}$.

Ks. S. Librowski wiele czasu i wysiłku poświęcił, powstałemu w 1956 r. w Lublinie Ośrodkowi Archiwów, Bibliotek i Muzeów Kościelnych oraz wydawanemu przez tę instytucję półrocznikowi Archiwa Biblioteki i Muzea Kościelne, którego

${ }^{15}$ Tamże, s.291-294.

${ }^{16}$ Tamże, s. 284-286.

${ }^{17}$ Tamże, s. 56-60.

${ }^{18}$ S. Librowski, Czterechsetlecie fundacji Seminarium Włocławskiego (1568-1968), ABMK, 17 (1968) s. 179-185.

${ }^{19}$ S. Librowski, Wystawa «Czterysta lat istnienia i działalności Seminarium Duchownego we Włoclawku (1568/69-1968/69)», ABMK, 22 (1971) s. 223-288.

${ }^{20}$ Librowski, Inwentarz, s.83-84.

${ }^{21}$ Tamże, s.304-317.

${ }^{22}$ Tamże, s.84-109.

${ }^{23}$ Tamże, s.206-209. 
został naczelnym redaktorem ${ }^{24}$. Jego staraniem pierwszy tom tego czasopisma ukazał się w 1959 r. Pismo cieszyło się zawsze wysokim poziomem redakcyjnym i naukowym i w dalszym ciągu jest bardzo cenione wśród historyków (Teka XIV $)^{25}$.

Zorganizowany przez ks. S. Librowskiego Pierwszy Zjazd Archiwistów, Bibliotekarzy i Muzeologów Kościelnych odbył się na Jasnej Górze 26-27 VI 1957 r., na którym to zjeździe wygłosił referat poświęcony problemom archiwów ${ }^{26}$. Warto pamiętać, że Ośrodek ABMK, organizował w 1961 r., 1967 r., 1989 r. i 1991 r. kursy ogólne dla archiwistów, a w 1969 r. i 1972 r. seminaria dla zakonnic (Teka XIV - XV). ${ }^{27} \mathrm{~W}$ tej materii cenne są też jego zapiski metodyczne, archiwalne i historyczne (Teka XXXII). ${ }^{28}$

Ks. S. Librowski podkreślał ścisły związek łączący archiwistykę z bibliotekami, bibliografią, chronologia, edytorstwem źródeł historycznych, genealogią i heraldyką oraz geografią historyczną $\left(\right.$ Teka XXX) ${ }^{29}$. Uważał, że nie można też po-

24 [S. Librowski, W. Nowodworski], Ośrodek Archiwów, Bibliotek i Muzeów Kościelnych (Ośrodek ABMK), ABMK, 1(1959) z.1, s. 10-17; tamże, Od Redakcji, s. 7-9; S. Librowski, B. Kumor, Do archiwów i bibliotek kościelnych w Polsce. Komunikat, ABMK, 4 (1962), s. 399-400; S. Librowski, [Ośrodek Archiwów, Bibliotek i Muzeów Kościelnych], AK, 55 (1957) s. 311-312; tenże, Stan i potrzeby archiwów kościelnych oraz program pracy na najbliższy okres, ABMK, 1(1959) z.1, s. 20-33; tenże, Archiwa, biblioteki i muzea kościelne. Podobieństwa i różnice. Próba rozgraniczenia, ABMK, 16 (1968) s. 5-18.

${ }^{25}$ Librowski, Inwentarz, s. 109-111; tenże, Dwadzieścia pięć tomów czasopisma Archiwa, Biblioteki i Muzea Kościelne, ABMK, 25 (1972) s. 5-38; tenże, Bibliografia zawartości czasopisma Archiwa, Biblioteki i Muzea Kościelne, tomy 1-50, ABMK, 52 (1986) s. 175-256; tenże, Bibliografia zawartości czasopisma Archiwa, Biblioteki i Muzea Kościelne, tomy 51-60, ABMK, 60 (1991) s. 586-592; tenże, Wykaz instytucji krajowych posiadajacych (w całości lub w części) czasopismo Archiwa, Biblioteki i Muzea Kościelne, ABMK, 30 (1975) s. 297-319; Archiwa, biblioteki i muzea kościelne.[ Na temat zbiorów i czasopisma z ks. prof. S. Librowskim] rozmawiał Romuald Szpor, „Życie i Myśl”, 26 (1976) nr 11, s. 67-75.

${ }^{26}$ S. Librowski, Pierwszy zjazd archiwistów bibliotekarzy i muzeologów kościelnych (1: Przebieg zjazdu, 3: Rezolucje zjazdu), ABMK, 1 (1959) z.1, s. 18-20, 56-59; tenże,[Zjazd archiwistów, bibliotekarzy i muzeologów kościelnych], AK, 55 (1957), s. 312-313

${ }^{27}$ Librowski, Inwentarz, s. 109-146; tenże, Kształcenie archiwistów przez Ośrodek Archiwów, Bibliotek i Muzeów Kościelnych, ABMK, 58 (1989) s. 11-24; tenże, Wykaz instytucji krajowych posiadajacych w catości lub w większej części czasopisma Archiwa, Biblioteki i Muzea Kościelne, ABMK, 53 (1986) s. 5-31; tenże, To już czterdzieści![tomów czasopisma Archiwa Biblioteki i Muzea Kościelne], ABMK, 40 (1980) s. 7-8; tenże, Pierwszy kurs dla pracowników archiwów kościelnych, AK, 54 (1957) s. 117-121; tenże, Pierwszy kurs archiwalny dla pracowników archiwów kościelnych, przeprowadzony w Lublinie w roku 1956, „Archeion”, 27 (1957) s. 325-333.

${ }^{28}$ Librowski, Inwentarz, s. 303-304; tenże, [Wypowiedzi w dyskusji:] Ogólnopolska konferencja dla kadry kierowniczej bibliotek teologicznych w Polsce, zorganizowana przez Ośrodek Archiwów, Bibliotek i Muzeów Kościelnych przy Katolickim Uniwersytecie Lubelskim w dniach 15-16 września 1981 roku w Lublinie, na temat: Problemy biblioteki teologicznej, ABMK, 44 (1982) s. 33,37-38, 46-47, 57, 81; tenże, Osiem prac metodycznych Ośrodka ABMK oraz zastosowanie ich w zbiorach kościelnych, ABMK, 4 (1962) s. 343-351.

${ }^{29}$ Librowski, Inwentarz, s. 299-300; tenże, Źródła do zabytkoznawstwa w archiwach kościelnych, ABMK, 6 (1963) s. 211-225. 
minać medalierstwa, muzealnictwa, numizmatyki, sfragistyki i źródłoznawstwa $(\text { Teka XXXI) })^{30}$.

W 1966 r. Ministerstwo Szkolnictwa Wyższego nadało ks. Librowskiemu stopień naukowy docenta nauk humanistycznych w zakresie historii Polski do XVIII w. i nauk pomocniczych historii. Z kolei nadanie mu tytułu profesora nadzwyczajnego miało miejsce w 1969 r., a tytułu profesora zwyczajnego w 1975 roku (Teki: XVIII-XX) ${ }^{31}$.

Ks. S. Librowski był znany w kręgach naukowych w Polsce i w świecie, dlatego często zapraszano go na różne zjazdy i konferencje krajowe i zagraniczne, $m$. in. do Austrii, Belgii, Francji, Holandii, Niemiec, Szwajcarii, Włoch czy USA. Jednak nie wyjeżdżał z kraju (Teka XXI) ${ }^{32}$.

Będąc znanym badaczem dziejów historii Kościoła otrzymywał wiele zamówień od różnych wydawnictw czy to instytucji państwowych np. PAN, a także kościelnych (Teka XXII) ${ }^{33}$.

Pracując naukowo prowadził obszerną korespondencję. Otrzymywał gratulacje, uznania i nagrody (Teki: XXIII-XXV, XXVIII). ${ }^{34}$ Dosyć obszerna jest też jego korespondencja świąteczna, towarzyska, jubileuszowa czy okolicznościowa, a obejmująca m. in. zaproszenia z okazji ślubów zakonnych, Pierwszej Komunii św., czy powiadomienia pogrzebowe (Teka VIII) ${ }^{35}$.

Jak już wcześniej wspomniano, ks. S. Librowski był bardzo zaangażowany w pracę archiwisty diecezji włocławskiej ${ }^{36}$.To z jego inicjatywy po zakończeniu II wojny światowej rozdzielono zasoby archiwalne od bibliotecznych. Do tego czasu w Archiwum Diecezjalnym we Włocławku, które nosiło nazwę Archiwum Kapituły Włocławskiej, znajdowało się własne archiwum, ale i archiwum biskupów włocławskich, także archiwum konsystorza generalnego włocławskiego oraz rękopisy biblioteczne. Te ostatnie zostały przekazane do biblioteki seminaryjnej $(\text { Teka XL-XLVI })^{37}$.

Angażując się w pracę archiwisty opracował statut archiwum. Omówił też sprawy związane ze scaleniem i wymianą oraz ekstradycją akt, a także ich mikro-

${ }^{30}$ Tenże, Inwentarz, s. 301-303; tenże, Program prac katedry nauk podstawowych i metodologii Instytutu Historii Kościoła Katolickiego Uniwersytetu Lubelskiego nad polskimi medalami religijnymi i medalikami, ABMK 36(1978), s. 61-78.

${ }^{31}$ Tenże, Inwentarz, s. 209-215.

${ }^{32}$ Tamże, s. 215-237.

${ }^{33}$ Tamże, s. 237-248.

${ }^{34}$ Tamże, s.249-284, 291-294.

${ }^{35}$ Tamże, s. 42-56.

${ }^{36}$ S. Librowski, Archiwum Diecezjalne we Włocławku w latach 1945-1958, Włocławek 1958; tenże, Archiwum Diecezjalne we Włoclawku, w: Archiwa diecezjalne w Polsce w powojennym czterdziestoleciu (1945-1985), ABMK, 53 (1986) s. 87-102.

${ }^{37}$ S. Librowski, Archiwum, „Encyklopedia Katolicka” (dalej: EK), t. 1, Lublin 1973, kol. 886887; tamże, Archiwa Kościoła Katolickiego w Polsce, kol. 877-886; tenże, Archiwum Diecezjalne we Włocławku. Dziat I: Dokumenty. Ser.I: Inwentarz realny, z.1-4, ABMK, 47 (1983) s. 5-106; 55 (1987) s. 5-99; 56 (1988) s. 7-94, 57 (1988) s. 7-57. 
filmowaniem ${ }^{38}$. Ponadto wiele uwagi poświęcił porządkowaniu zasobu, obsłudze kwerendzistów, a także sprawom socjalnym pracowników (Teka X-XI) ${ }^{39}$. Statut archiwum zatwierdził 7 III 1953 r. ówczesny administrator diecezji, biskup Franciszek Korszyński ${ }^{40}$. Nowy statut i regulamin Archiwum Diecezjalnego we Włocławku przygotowany również przez ks. S. Librowskiego nadał w 1960 r. biskup Antoni Pawłowski ${ }^{41}$.

Cały zasób Archiwum Diecezjalnego we Włocławku składa się z trzech działów, które obejmują ok. 9 tys. ksiąg i fascykułów. Archiwum liczy ok. 1200 dokumentów pergaminowych (najstarszy z 1228 r.), ok. 3000 dokumentów papierowych oraz ok. 200 map i planów z terenu diecezji. Jest też ok. 2000 fotografii księży i budowli kościelnych. Od 1947 r. gromadzone są też mikrofilmy ${ }^{42}$. Najcenniejszy ze wszystkich jest zespół, który zawiera akta dotyczące historii diecezji, a więc: archiwum diecezji kujawskiej i pomorskiej (do 1818 r.), archiwum części byłej archidiecezji gnieźnieńskiej, która w $1818 \mathrm{r}$. weszła w skład diecezji kujawsko-pomorskiej, archiwum diecezji kujawsko-kaliskiej (1818-1925) i archiwum diecezji włocławskiej (od 1925 r.) $)^{43}$.

W spuściźnie naukowej ks. S. Librowskiego, dotyczącej diecezji włocławskiej, na szczególną uwagę zasługuje sporządzony przez niego w 1947 r. wykaz oryginalnych dokumentów samoistnych dotyczący diecezji kujawskiej i pomorskiej z XII i XIII w., a przechowywanych w Archiwum Diecezjalnym we Włoclawku (Teka XXXVII). ${ }^{44}$

W badaniu dziejów diecezji włocławskiej ks. S. Librowski wskazywał, że podwaliny do jej istnienia położyli Bolesław Krzywousty i legat papieski Idzi

${ }^{38}$ S. Librowski, Archiwa, biblioteki i muzea kościelne. Podobieństwa i różnice. Próba rozgraniczenia, ABMK 16 (1968) s. 5-18.

${ }^{39}$ Tenże, Inwentarz, s. 60-82; tenże, Sprawozdanie z działalności Archiwum Diecezjalnego we Włocławku [za lata] 1945-1958, ABMK, 1 (1959) z. 1, s. 137-159; tenże, Rejestracja archiwaliów i starych druków na terenie diecezji wloctawskiej w latach 1960-1962, ABMK, 5( 1962), s. 347-359; tenże, Pierwszy kurs archiwalny dla pracowników archiwów kościelnych, AK, 54 (1957), s. 117121.

${ }^{40} \mathrm{Już}$ w $1521 \mathrm{r}$. wybudowano przy katedrze włocławskiej kapitularz składający się z dwóch sal, w których mieściło się archiwum i biblioteka kapitulna. W czasie prac związanych z przebudowa katedry w latach 1891-1893 zbudowano nad kapitularzem cztery sale, w których do dzisiejszego dnia mieści się archiwum diecezjalne. W 1942 r. archiwalia i rękopisy wywieziono do Poznania. Większość archiwów parafialnych została złożona w Łodzi i Poznaniu oraz w klasztorze filipinów w Gostyniu. Rewindykacją akt po zakończeniu II wojny światowej zajęli się księża: Józef Iwanicki i Stanisław Olejnik; S. Librowski, Sprawozdanie z działalności Archiwum Diecezjalnego we Włoctawku 1945-1958, ABMK, 1 (1959), s. 138-139.

${ }^{41}$ S. Librowski, Projekt statutu i regulaminu archiwum diecezjalnego, ABMK, 1 (1960) z.2, s. 8-15; tenże, Statut i regulamin Archiwum Diecezjalnego we Włocławku,[nadał] Antoni Pawłowski, biskup włocławski, KDW. 54 (1960) s. 383-391.

${ }^{42}$ Librowski, Inwentarz, s. 154.

${ }^{43}$ Niedokładne spisy akt posiadało archiwum już w XVI w; Librowski, Inwentarz, s. 155.

4429 oryginałów włocławskich z XIII-XVII w. zostało udostępnionych na „Wystawę Kujawską" w Muzeum Ziemi Kujawskiej we Włocławku; Librowski, Inwentarz, s.323-324; IADW. Dokumenty samoistne, t.1-7, Włocławek 1994-1999. 
z Tuskulum (nie ma bulli erekcyjnej diecezji włocławskiej). Spóźnionym dokumentem erekcyjnym jest natomiast bulla protekcyjna papieża Eugeniusza III wystawiona dla biskupa Wernera w $1148 \mathrm{r}$. i sankcjonująca istnienie diecezji kruszwickiej oraz przynależność Pomorza Gdańskiego do Polski. Należy pamiętać, że terytorium diecezji w tej fazie dziejów, począwszy już od XIII w., ulegało różnym zmianom czy to na skutek interwencji Krzyżaków, czy też w wyniku sporu z diecezją płocką o parafie leżące po prawej stronie Wisły: Szpetal, Bobrowniki i Przypust (XIV w.), a potem Ciechocin, Nowogród i Dobrzejewice (XVII w.). Podobnie było w przypadku Wolborza i okolicznych parafii, które w 1764 r. włączono, w zamian za Bydgoszcz, do diecezji włocławskiej ${ }^{45}$.

Szczególne znaczenie w odsłanianiu dziejów diecezji włocławskiej w jej najstarszej fazie miało opublikowanie przez ks. Librowskiego ineditów do 1475 r., a obejmujących trzynaście dokumentów dotyczy lat 1300-1400, trzydzieści osiem dokumentów z I połowy XV w., i trzydzieści jeden z drugiej połowy XV w.(Teka $\mathrm{LXXXIII}^{46}$.

Do czasu przeniesienia stolicy biskupiej do Włocławka, diecezją kruszwicką kierował archidiakon. Po zmianach w 1123 r. diecezję kujawską i pomorską podzielono na trzy archidiakonaty: włocławski, pomorski i kruszwicki; urząd archidiakona istniał do końca istnienia archidiecezji kujawskiej i pomorskiej, ale jego funkcja ograniczała się tylko do roli wizytatora, co było związane z wprowadzeniem w XIII w. urzędu oficjała (zastępca biskupa w sprawach sądowych i administracyjnych). Dla archidiakonatów włocławskiego i kruszwickiego powstał oficjałat generalny włocławski z siedzibą we Włocławku, a dla archidiakonatu pomorskiego drugi oficjałat generalny w Gdańsku. W połowie XVI w. powołano także oficjałat foralny w Bydgoszczy (1748 r.), którego siedzibę w 1764 r. przeniesiono do Świecia. Po 1772 r. utworzono nowy oficjałat foralny w Tczewie (istniał do 1793 r.). Po I rozbiorze Polski (1772 r.) w ramach diecezji poznańskiej powstał oficjałat kruszwicki, który w 1817 r. biskup Franciszek Malczewski (1815-1818) powierzył jurysdykcji biskupa poznańskiego Tymoteusza Gorzeńskiego (Teka LXX) ${ }^{47}$.

W tym miejscu warto zaznaczyć, że na przestrzeni XIX i XX w. na rozległym

${ }^{45}$ S. Librowski, Inwentarz realny dokumentów Archiwum Diecezjalnego we Włocławku. Dokumenty samoistne, t. 1-7, Włocławek 1994-1999; Akta biskupów kujawsko-pomorskich (ABKP), Inwentarz dóbr i dochodów biskupstwa włocławskiego z r. 1534, Archiwum Diecezji Włocławskiej, sygn. ABKP, A. gosp. 2(134), k. 44v-54v.

${ }^{46}$ Librowski, Inwentarz, s. 391; tenże, Trzynaście nie drukowanych oryginałów pergaminowych Archiwum Diecezjalnego we Włocławku z lat1300-1400, ABMK, 55 (1987) s. 129-153; tenże, Trzydzieści osiem nie drukowanych oryginałów pergaminowych Archiwum Diecezjalnego we Włoctawku z pierwszej połowy XV wieku, ABMK, 56 (1988) s. 189-309; tenże Trzydzieści jeden nie drukowanych oryginatów pergaminowych Archiwum Diecezjalnego we Włocławku z drugiej połowy XV wieku. Trzecie ćwierćwiecze, ABMK, 57 (1988), s. 201-272; tenże, Wizytacje diecezji włocławskiej, cz.1: Wizytacje diecezji kujawskiej i pomorskiej, t.1: Opracowanie archiwalno-źródłoznawcze, z.1. Wstęp ogólny, ABMK, 8 (1964) s. 5-186.

${ }^{47}$ Librowski, Inwentarz, s. 375; tenże, Diecezja włocławska oraz jej wkład w życie Kościoła i Narodu, KDW, 49 (1966) s. 265-274; W. Patykiewicz, Późniejsze oficjałaty gnieźnieńskie, „Roczniki Teologiczno-Kanoniczne", 5 (1958) z. 4, s. 117-122. 
terenie diecezji kujawsko-kaliskiej powstały tzw. komisariaty, będące namiastką dawnych archidiakonatów lub bardziej oficjałatów; w latach 1818-1925 funkcjonowały trzy takie ośrodki oficjalskie (od $1918 \mathrm{r}$. wikariaty biskupie), a w latach 1926-1931 tylko dwa (Włocławek i Kalisz). Po 1945 r. powstały trzy rejony diecezji: włocławski, kaliski i koniński, a obecnie są trzy wikariaty biskupie (Teka LXX) $)^{48}$.

Terytorium diecezji dzieliło się początkowo na parafie (ośrodki duszpasterskie), które zostały zorganizowane w XII-XIV w., a następnie na okręgi administracyjne, zwane dekanatami. Bywały przypadki, iż niektóre parafie (XIV-XV w) posiadały po dwóch i więcej proboszczów, a to m.in. dlatego, że w parafii było niekiedy kilku kolatorów i niejednokrotnie nie potrafili uzgodnić między sobą jednego proboszcza. W diecezji kujawskiej i pomorskiej takich przypadków było ok. $10\left(\right.$ Teka LXX) ${ }^{49}$.

Najstarszy spis parafii związany jest z wykazem świętopietrza z lat 1325-1327 oraz wizytacjami poszczególnych parafii. Ogólnie biorąc w okresie kruszwickim powstały 23 ośrodki kościelne, a w okresie wczesnowłocławskim (1123-1325) 67 parafii. Faktem jest, że w XV w. na terenie diecezji kujawskiej i pomorskiej istniały już 123 parafie. Źródłem tych danych jest m. in. opracowanie przez ks. S. Librowskiego wizytacji za lata 1123-1421(Teka XLVIII) ${ }^{50}$. Najstarsze akta konsystorza generalnego włocławskiego pochodzą jednak dopiero z $1421 \mathrm{r}$., a archiwa parafialne diecezji kujawskiej i pomorskiej zachowały się dopiero od połowy XVI w.; dekanalne dopiero od początku XVIII w. Na uwagę zasługuje fakt, że podział diecezji na dekanaty jest znany dokładnie dopiero od XVI w., a od końca XVIII w. obrazują go drukowane Katalogi, czyli Roczniki diecezji (Teka LX) ${ }^{51}$. W tym miejscu warto zaznaczyć, że na terenie diecezji kujawskiej i pomorskiej, począwszy do XIII w., istniały, zarówno w mieście, jak i na wsi, tzw. prepozytury parafialne, czyli instytucje złożone z kilku mansjonarzy, z prałatem na czele. Najstarsza z nich to prepozytura parafii Salino, dekanatu lęborskiego, w archidiakonacie pomorskim (1268). Z kolei najstarszymi na Kujawach sa prepozytury powstałe na przestrzeni XV-XVI w., m.in. w: Chodczu (1461r.), Służewie (1477 r.), Radziejowie (1520 r.), Raciążku i Inowrocławiu (Teka LXX) ${ }^{52}$.

Zmiany terenowe i organizacyjne diecezji, wykaz parafii i kościołów oraz archidiakonów, czyli wizytatorów kruszwickich, włocławskich i pomorskich są uwzględniane w dokumentach z lat 1422-1563; dotyczą też okresów działalności poszczególnych biskupów (Teka XLVIII) ${ }^{53}$.

${ }^{48}$ Komisariaty biskupie funkcjonowały zwłaszcza w diecezji chełmińskiej, katowickiej, częstochowskiej i płockiej. Librowski, Inwentarz, s. 376.

${ }^{49} \mathrm{Na}$ mocy dokumentu wystawionego przez króla Bolesława Śmiałego w 1065 r. dla opactwa benedyktynów w Mogilnie mieli oni patronat nad niektórym parafiami, np. Włocławek, Słońsk czy Przepust; Librowski, Inwentarz, s. 377.

${ }^{50}$ Tamże, s. 352; tenże Wizytacje diecezji włocławskiej, s. 5-186.

${ }^{51}$ Librowski, Inwentarz, s.366; I. Subera, Terytorium diecezji włoctawskiej i pomorskiej, „Prawo Kanoniczne", 4 (1961) s.681-768.

${ }^{52}$ Librowski, Inwentarz, s. 377.

${ }^{53}$ Tamże, s. 352. 
Bogaty w materiały źródłowe jest też okres do1818 r., co ukazał ks. S. Librowski w tomie drugim Wizytacji Diecezji Włocławskiej. Przedstawił on materiały obejmujące wyciagi ze źródeł prawno-historycznych na temat wizytacji kanonicznych oraz luźne zapiski o instrukcjach wizytacyjnych. Nade wszystko uwzględnił wizytacje z XVI w., z czasów biskupa Stanisława Karnkowskiego. Dużo miejsca poświęcił także wizytacjom biskupów: Hieronima Rozrażewskiego, Andrzeja Lipskiego, Macieja Łubieńskiego, Mikołaja Gniewosza, Kazimierza Floriana Czartoryskiego, Bonawentury Madalińskiego, Stanisława Dąbskiego, Stanisława Szembeka, Felicjana Konstantego Szaniawskiego, Krzysztofa Antoniego Szembeka, Walentego Aleksandra Czapskiego, Antoniego Sebastiana Dembowskiego, Antoniego Kazimierza Ostrowskiego, Józefa Ignacego Rybińskiego oraz Franciszka Malczewskiego (Teka XLIX) ${ }^{54}$.

Wizytacjom diecezji kujawsko-kaliskiej oraz włocławskiej ks. S. Librowski poświęcił także kolejny tom trzeci, pt. Wizytacje Diecezji Włocławskiej. Uwzględnił w nich ogólne dane o diecezjach i ich podziałach oraz zespołach archiwalnych, a także ekstradycjach tych dokumentów w 1926 r. do Łodzi i Częstochowy. Podał również częściową bibliografię dotyczącą tych wizytacji. Szczególną uwage zwrócił jednak na wizytacje dekanalne, przeprowadzone przez biskupa Koźmiana w 1824 r.; jego wizytację generalną w katedrze 'włocławskiej, a także wizytacje dekanatów: brzeźnickiego, częstochowskiego, piotrkowskiego i radomskowskiego (1821-1838). Omawiając wizytacje przedstawił $\mathrm{m}$. in. pismo skierowane ogólnie do nieznanego z nazwiska Dziekana w sprawie nadsyłania sprawozdań wizytacyjnych do biskupa Aleksandra Bereśniewicza (ok.1890 r.). Cenny jest też, przedstawiony przez ks. S. Librowskiego, kwestionariusz wizytacyjny obejmujący 114 pytań zok. 1906r., czylizczasów biskupa StanisławaZdzitowieckiego.(Teka L) $)^{55}$.

Duże znaczenie w ukazaniu dziejów diecezji włocławskiej, szczególnie w jej fazie kujawsko-kaliskiej, ma czteroczęściowe dzieło ks. S. Librowskiego, pt. Repertorium akt wizytacji kanonicznych dawnej Archidiecezji Gnieźnieńskiej. Autor ukazał w nim formę odbywania wizytacji, samo jej przeprowadzenie, aktualny stan archidiecezji tamtego okresu, środki zaradcze oraz zachowane i zaginione akta (Teka LI i LIII-LIV) ${ }^{56}$. Ponadto omówił wizytacje innych diecezji, które w jakiejś mierze pośrednio były związane z diecezją włocławską (Teka LII $)^{57}$.

Wizytacje dotyczyły przede wszystkim parafii. Dla niektórych z nich zachowały się zbiory rozporządzeń władz duchownych i świeckich od I rozbioru Polski do I wojny światowej włącznie. W Archiwum Diecezjalnym własne kopiariusze dawnej diecezji kujawsko-kaliskiej posiadają parafie: Lutomiersk, Suchcice i Warta. Ponadto istnieje też seria akt metrykalnych (najstarsze z Ciążenia z 1562

${ }^{54}$ Librowski, Inwentarz, s.354-356; tenże, Nieco wiadomości o grobie i szczqtkach pośmiertnych prymasa Karnkowskiego, KDW, 46(1963), s. 202-204; tenże, Biskup Hieronim Rozrażewski jako humanista i mecenas, ABMK, 11 (1965) s. 201-263.

${ }^{55}$ Librowski, Inwentarz, s.356-357.

${ }^{56}$ Tamże, s. 357-358, 359-361.

${ }^{57}$ Tamże, s.358-359; tenże, Podział obecnej diecezji chetmińskiej na komisariaty, czyli delegatury biskupie, ABMK, 29 (1973) s. 281-299. 
roku). Skrócony spis akt metrykalnych do 1808 r. został sporządzony przez archiwistkę, s. Laurencję Jędrzejczak w 1965 r., a kolejny, obejmujący lata 1808-1939 r., został przez nią wykonany w 1970 r.(Teka XLIV) ${ }^{58}$.

Przygotowując inwentarz dokumentów diecezji kujawskiej i pomorskiej, ks. S. Librowski uwzględnił także dzieje katedry św. Wita w Kruszwicy (spłonęła w 1096 r) oraz katedry św. Piotra i Pawła w tym mieście (XI w.), a także regesty ważniejszych wpisów m.in. do akt biskupów: Zbigniewa Oleśnickiego i Krzesława z Kurozwęk (XV w), a następnie: H. Rozrażewskiego (XVI w.), Wojciecha Baranowskiego, Pawła Wołuckiego, Macieja Pstrokońskiego, Wawrzyńca Gembickiego, Mikołaja Gniewosza z Oleksowa, czy sufragana Franciszka Ląckiego, $(\mathrm{XVI} / \mathrm{XVII} \text { w. })^{59}$. W swoich badaniach wskazał na istnienie znacznej ilość dokumentów dotyczących diecezji kujawskiej i pomorskiej, które znajdują się w: Archiwum Diecezji Pelplińskiej, Archiwum Państwowym w Gdańsku, Muzeum Narodowym w Krakowie czy w Archiwum Głównym Akt Dawnych w Warszawie. Szczególną uwagę zwrócił na spis dokumentów z lat 1218-1568, odnoszących się do diecezji kujawskiej i pomorskiej, a zamieszczonych w zbiorze wydanym przez A. Theinera, pt. Vetera monumenta Poloniae et Lithuaniae, t. I, Romae 1860 (Teka XXXVIII) $^{60}$.

Cennym źródłem do dziejów diecezji są, wskazane przez ks. S. Librowskiego, kopiariusze dokumentów z XIV-XVIII w. (18). Niektóre z nich w części zaginęły (kopiariusz siódmy), z niektórych, jak np. z kopiariusza ósmego, wypruto i przekazano pewną część do archiwum w Gnieźnie. Jeszcze inny (szósty) został zabrany najpierw przez Niemców, następnie z Berlina w 1945 r. przez wojska sowieckie i zwrócony dopiero w $1958 \mathrm{r}$.

Należy też podkreślić wysiłek ks. S. Librowskiego związany z kwerendą w Archiwum Archidiecezji Gnieźnieńskiej, która dotyczyła głównie terenów znajdujących się po 1818 r. w granicach diecezji kujawsko-kaliskiej. Na uwagę zasługują: kopiariusz retrospektywny „numer zerowy” autorstwa kanonika Władysława z Poznania, sporządzony w XV w., a który zawiera wpisy z XIII-XV w.

${ }^{58} \mathrm{Na}$ znaczenie dokumentów archiwalnych zwrócił uwagę już pod koniec XVI w. biskup Hieronim Rozrażewski i zaczął gromadzić w archiwum kapituły włocławskiej dokumenty dotyczące poszczególnych parafii w diecezji kujawskiej i pomorskiej. W połowie XIX w. także proboszczowie nadsyłali takie dokumenty. Polecenie przesyłania do Kurii Diecezjalnej akt powstałych do $1800 \mathrm{r}$. wydał w 1936 r. biskup K. Radoński. Rejestracji archiwaliów i starych druków na terenie diecezji włocławskiej pod protektoratem biskupa A. Pawłowskiego dokonał w latach 1960-1962 ks. Librowski. Wszystkie archiwalia zebrał on w spisie w trzech egzemplarzach. Podobnego spisu, a zarazem zwiezienia z całej diecezji włocławskiej materiałów archiwalnych dokonał ks. W. Kujawski w latach 1978-1979; S. Librowski, Inwentarz, s.347; tenże, Rejestracja archiwaliów i starych druków na terenie diecezji włocławskiej $w$ latach 1960-1962. I: Sprawozdanie z rejestracji dokonanej $w$ roku 1960, ABMK, 5 (1962) s. 347-359; II: Sprawozdanie z rejestracji dokonanej w latach 1961-1962, ABMK, 6 (1963) s. 269-278.

${ }^{59}$ Librowski, Inwentarz, s. 324; tenże, $Z$ dziejów katedry, a następnie kolegiaty św. Wita $w$ Kruszwicy. I: Katedra, potem kolegiata św. Wita do roku 1428, ABMK, 15(1967) s. 251-269; tenże, Rola Kruszwicy w dziejach Narodu i Kościoła Polskiego, KDW, 49 (1966) s. 218-230.

${ }^{60}$ Librowski, Inwentarz, s. 325; S. Maternowski, Dokumenty kujawsko-pomorskie biskupów w XIII wieku. (Przyczynek do dyplomatyki polskiej), Warszawa 1925. 
oraz kopiariusze: od pierwszego do siódmego. Wielkie znaczenie ma też kopiariusz nowy, sporządzony w XVIII w. z kontynuacją do XIX w., retrospektywny, zawierający wpisy od XII w. Cenne są też pomoce archiwalne, jak: sumariusze dokumentów (XVI-XVII w.), repertoria ważniejszych wpisów do wybranych akt biskupich (XVII w.), czy indeksy dokumentów (Teka XXXIX) ${ }^{61}$.

Cenne są również, zebrane przez ks. S. Librowskiego, źródła dotyczące miast: Uniejowa i Łodzi oraz źródła zebrane do badań demograficznych na Kujawach i Pomorzu z uwzględnieniem czasów przedmetrykalnych, a także tabele statystyczne z wizytacji generalnych diecezji kujawskiej i pomorskiej z lat 1779-1783, tj. rządów biskupa J. Rybińskiego czy też sprawy dotyczące ludności większych miast na Kujawach z XVI-XVIII w. (Teka LXIII) ${ }^{62}$.

Ks. S. Librowski cały inwentarz zespołu akt biskupów kujawskich i pomorskich ujął w trzy serie: akta gospodarcze zachowane od 1531 r., akta działalności, zwane krótko „aktami” (ocalałe od 1479 r.) i akta wizytacyjne zachowane od 1576 r. Z kolei serię gospodarczą podzielił na trzy podserie: akta prawno-majątkowe np. Liber Beneficiorum diecezji włocławskiej (powstał 1560 r.), rachunki (przychody i wydatki) oraz wizytacje majątków i dziesięcin (XVI-XVIII w.). W serii akt działalności, znajdują się wykazy akt biskupów włocławskich wraz z administratorami i wikariuszami kapitulnymi. W tym miejscu warto zaznaczyć, że obszerną korespondencję zostawili po sobie biskupi: Maciej Drzewiecki (XVI w.), Andrzej Zebrzydowski (XVI w.),Jakub Uchański (XVI w.), S. Karnkowski (XVI w.), H. Rozrażewski (XVI w.),Maciej Łubieński (XVII w.), Jan Gembicki (XVII w.) K. Szembek (XVIII w.), A.S. Dembowski (XVIII w.), A. K. Ostrowski (XVIII w.) i J. Rybiński (XVIII/XIX w.). Natomiast materiały polityczne i historyczne zostawili biskupi: M. Drzewiecki, S. Karnkowski, H. Rozrażewski. Diariusz po sobie zostawił biskup A. S. Dembowski (Teka XL) ${ }^{63}$.

Ostatnią serię zespołu biskupiego tworzy seria akt wizytacyjnych począwszy od 1123 r. aż do 1421 r. Do nich też należy szczegółowy wykaz akt wizytacyjnych archidiakonatów, które do 1821 r. należały do archidiecezji gnieźnieńskiej: gnieźnieńskiego, kaliskiego, łęczyckiego, wieluńskiego, uniejowskiego i krotoszyńskiego. Z historią diecezji kujawsko-pomorskiej związane są także akta przekazane przez konsystorz kujawski w 1821 r. i 1822 r. do Gniezna oraz Gdańska, a które od 1824 r. zgromadzono w Pelplinie w dziale Gedanensia. Inwentarz akt tamtejszego archiwum zawarty jest w VII działach. Na uwagę zasługują w tym dziale akta archiwum konsystorza gdańskiego, zwanego też pomorskim. Najstarsze z nich sięgają lat 1467-1588. W czasie II wojny światowej zostały wywiezione do

${ }^{61}$ Ks. S. Librowski posiadał mikrofilmy kopiariuszy od piątego do szóstego i od jedenastego do dwunastego. Istnieją także mikrofilmy kopiariuszy począwszy od „numeru zerowego” do kopiariusza nowego tzw. kopiariuszy gnieźnieńskich; Librowski, Inwentarz, s.326-332; tenże, Sumariusz wpisów kopiariusza kapituly kolegiackiej w Lowiczu z przełomu XVIII $i$ XIX wieku (z kontynuacja do roku 1961), ABMK, 34 (1977) s.191-291.

${ }^{62}$ Librowski, Inwentarz, s.385

${ }^{63}$ Tamże, s. 334 
Marburga (Teka XL) ${ }^{64}$.

$\mathrm{Na}$ szczególne uznanie zasługują też, dokonane przez ks. S. Librowskiego odpisy akt biskupich z XVII-XVIII w.; za najważniejsze uznać należy dokumenty: fundacyjne, erekcyjne, inkorporacyjne, dotyczące organizacji, administracji, wizytacji itp.(Teki LXXIV-LXXV) ${ }^{65}$.

Warto zaznaczyć, że od XIV w. biskupi, oprócz wielkiego wpływu na życie diecezji, zaczęli również odgrywać ważną rolę polityczną np. w przezwyciężeniu rozbicia dzielnicowego. Przykładem są biskupi: Gerward (XIV w.), czy Maciej z Gołańczy (XIV w.). Pełnili oni również funkcję wiceprymasowską. Ks. Librowski omówił dość szczegółowo wiceprymasostwo biskupów włocławskich, które przyznano im po wieloletnim sporze z biskupami poznańskimi w $1532 \mathrm{r}$. Nadany wówczas przywilej jako pierwszy wykorzystał biskup S. Karnkowski koronując na króla Polski Stefana Batorego w 1576 r. W historii Kościoła w Polsce z biskupstwa włocławskiego na biskupstwo krakowskie przeszło 7 biskupów, a na arcybiskupstwo gnieźnieńskie aż 18. Wyboru biskupa początkowo dokonywali panujący, a następnie kapituła katedralna. Od XV w. królowie uzyskali przywilej wyznaczania kandydata na biskupa, którego przedstawiano kapitule, a ta zazwyczaj jednogłośnie dokonywała wyboru i przedstawiała go papieżowi, który dokonywał prekonizacji. I chociaż trudno dzisiaj podać dokładny spis biskupów kruszwickich i włocławskich, to jednak większość z nich, która jest znana, ma już opracowane biogramy. Wiele z nich ks. S. Librowski zamieścił w Polskim słowniku biograficznym oraz Encyklopedii Katolickiej (Teka LXIII) ${ }^{66}$. Miał on też zamiar opublikować dzieło pt.: Libri ordinandorum episcoporum Vladislaviensium, które zawierałaby życiorysy biskupów włocławskich od 1480 r. Zbierał także materialny do edycji dotyczącej testamentów biskupów i kapłanów diecezji kujawskiej i pomorskiej (Teka LXXIII) ${ }^{67}$.

Szczególnie wiele uwagi poświęcił ks. S. Librowski biskupowi H. Rozrażewskiemu (1581-1600). Życie i działalność tego biskupa opracował w swojej pracy doktorskiej, którą obronił na Uniwersytecie Warszawskim w 1951 r.(Teka LXVII) ${ }^{68}$. Kolejnym ordynariuszem włocławskim, opisanym przez ks. S. Librowskiego, był biskup K. Radoński (1929-1951). Odnosząc się do czasów II wojny światowej podkreślił jego wyjazd z diecezji na początku września 1939 r. Nie

${ }^{64}$ Tamże, s.333-339; tenże, Wizytacje Diecezji Włocławskiej, s. 5-186; tenże, Wizytacje w latach 1123-1421, ABMK, Lublin 1965; A. Tomczak, Kancelaria biskupów włocławskich w okresie Księi Wpisów, Toruń 1964; S. Chodyński, Włocławska Diecezja, w: „Encyklopedia Kościelna”, t.2, Warszawa 1913, s.55-80.

${ }^{65}$ Librowski, Inwentarz, s. 385-386.

${ }^{66}$ Tamże, s. 368.

${ }^{67}$ Tamże, s. 385.

${ }^{68} \mathrm{~W}$ pracy omówił również oficjałów, duchowieństwo, innowierców oraz sprawy Kościoła na sejmach w XVI w. Wiele uwagi poświęcił seminarium duchownemu, biskupom pomocniczym, synodom, wizytacjom i zakonom; Librowski, Inwentarz, s. 372-373; tenże, Biskup Hieronim Rozrażewski jako humanista i mecenas, ABMK, 11 (1965) s. 201-263. 
pominął też jego sufragana, kapelana, a nawet lokaja i szofera ${ }^{69}$.

Biskupi włocławscy, pełniąc zaszczytne funkcje w Kościele i w państwie, posiadali dość wysokie uposażenie, które otrzymali głównie z nadań królewskich i książęcych (XII-XIII w.), a także różnych zapisów i dziesięcin. W skład dóbr biskupich w pewnym okresie dziejów wchodziło aż 7 miast i miasteczek oraz 120 wsi. Ich dobra stanowiły tzw. klucze: włocławski, lubotyński, ciechociński, raciążski, wolborski, łaznowski, smardzewicki, grabicki, czarnociński, niesółkowski, subkowski, komorski i piórkowski. Wszystkie te dobra utracili jednak na skutek rozbiorów Polski. Od tego czasu utrzymanie zarówno biskupa, jak i agend kurialnych przeszło najpierw na rządy państw zaborczych, a potem władz wolnej Polski, obecnie tylko wiernych (Teka XL) ${ }^{70}$.

Ze względu na działalność polityczną biskupów kujawsko-pomorskich oraz rozległość terytorialną diecezji, pomocą służyli im od początku XIV w. sufragani; nie posiadali oni żadnej władzy jurysdykcyjnej. Ich posługa miała charakter czysto liturgiczny. Dlatego pierwszych sufraganów wybierali biskupi kujawscy i pomorscy spośród duchowieństwa zakonnego, a potem spośród członków kapituły katedralnej. Sama godność biskupa pomocniczego nie wiązała się z żadnym awansem w kapitule; jego uposażenie było jednak o wiele wyższe niż zwykłego kanonika, a składały się na nie dochody z parafii: Kowal, Fordon, Dóbrcz i Lubomin. Najczęściej ordynariusze włocławscy mieli tylko jednego sufragana, chociaż bywało i tak, że część pomorska diecezji miała swojego sufragana w Gdańsku; za biskupa S. Zdzitowieckiego oraz po II wojnie światowej było przeważnie aż dwóch ${ }^{71}$.

Ważną funkcję w historii diecezji miały konsystorze, zarówno generalne, jak i foralne (okręgowe) ${ }^{72}$. Po 1818 r. konsystorz kaliski był generalnym pierwszym ${ }^{73}$, a włocławski (kujawski) - generalnym drugim. W 1887 r. konsystorz generalny kaliski został obniżony do foralnego ${ }^{74}$. Należy pamiętać, że przed przyłączeniem terenów z archidiecezji gnieźnieńskiej w 1818 r. do diecezji kujawsko-kaliskiej funkcjonowały trzy konsystorze: foralny w Wieluniu (akta zachowane od 1459 r.), generalny w Łowiczu (XVIII/XIX w.) i foralny w Uniejowie (Teka XLI) ${ }^{75}$. Natomiast po 1818 r. w celu sprawnego zarządzania biskup A. Wołowicz ustano-

${ }^{69}$ S. Librowski, Materiały do dziejów diecezji włoctawskiej czasu wojny 1939-1945. Seria 1 ogólna, Lublin 1979, s.209-212.

${ }^{70}$ Librowski, Inwentarz, s.336; Revisio bonorum episcopatus Wladislaviensis facta a. 1598, ed. L. Żytkowicz, Torunii 1950; W. Kujawski, Zarys dziejów diecezji włocławskiej, w: Diecezja włocławska 2000, Włocławek 2001, s.33-34; K. Górski, Dobra biskupów włocławskich w Ziemi Dobrzyńskiej w świetle dokumentów Archiwum Diecezjalnego we Włocławku, SW, 9 (2006) s.661368.

${ }^{71}$ Kujawski, Zarys dziejów, s.34; S. Chodyński, Biskupi sufragani włocławscy, Włocławek 1906.

${ }^{72}$ S. Chodyński, Konsystorze w diecezji kujawsko-pomorskiej, Włocławek 1914.

${ }^{73}$ Konsystorz kaliski foralny istniał od 1459 r. Jego akta w $1888 \mathrm{r}$. przewieziono do Włocławka. W latach 1945-1958 r. Rosjanie przechowywali go w Moskwie; Librowski, Inwentarz, s.340.

${ }^{74}$ Tamże, s.340.

${ }^{75}$ Wszystkie akta tych konsystorzy przewiezione zostały w 1888 r. do Włocławka; Librowski, Inwentarz, s.341 
wił wtedy aż dwa konsystorze generalne: w Kaliszu i Włocławku, a jego następca biskup J. Koźmian ustanowił jeszcze konsystorz foralny w Piotrkowie Trybunalskim. Z tego okresu zachowało się wytworzone przez biskupów I połowy XIX w. rezydujących w Kaliszu archiwum bp Andrzeja Wołowicza, bp Józefa Koźmiana i bp Walentego Tomaszewskiego, w którym możemy wyróżnić dwie serie: akta działalności oraz akta personalne duchowieństwa z lat 1818-1925 (Teka XLII) ${ }^{76}$. Zachowały się też akta konsystorza generalnego włocławskiego i konsystorza piotrkowskiego z I połowy XIX w. Natomiast nie zachowało się archiwum biskupów kujawsko-kaliskich z lat 1851-1920 r. Spłonęło ono w wyniku agresji sowieckiej na Włocławek w 1920 r. Akta te obejmowały rządy biskupów: M. Marszewskiego, W. T. Chościaka Popiela, A. Bereśniewicza i S. Zdzitowieckiego. Zachowały się tylko akta konsystorza piotrkowskiego, które w 1945 r. podzielono między diecezje: częstochowską i łódzką. Niektóre opalone akta przeleżały, pomimo wojny, we Włocławku i ks. Librowskiemu udało się wiele z nich odtworzyć (Teka XLII $)^{77}$.

W dziejach diecezji szczególną funkcję pełniły także kapituły, czyli korporacje duchowieństwa, które rządziły się własnymi statutami. Na pierwszym miejscu była to kapituła katedralna, która stanowiła swoistego rodzaju senat biskupa, a której to kapituły ordynariusz musiał się w pewnych sytuacjach radzić, a niekiedy nawet uzyskać jej zgodę; kapituła prowadziła swoją dokumentację. W przypadku śmierci biskupa lub jego translokacji na inną stolicę kapituła przejmowała rządy w diecezji, wyznaczając ze swego grona administratora, tj. wikariusza kapitulnego. W pewnym okresie dziejów kapituła włocławska decydowała nawet bezpośrednio czy też pośrednio o wyborze biskupa i wprowadzała go w urząd. W historii diecezji, zwłaszcza w XII w., istniały nawet dwie kapituły katedralne o jednakowych prawach: kapituła św. Piotra i Pawła w Kruszwicy (Teka LXV) ${ }^{78}$ i powstała w 1148 r. kapituła katedralna we Włocławku, uważana za jedną z najstarszych w Polsce. Szczątkowe wiadomości o poszczególnych prałatach kapituły włocławskiej pochodzą z 1215 r.; pełny wykaz kanoników istnieje z 1227 r. Członkowie kapituły musieli posiadać pochodzenie szlacheckie (do 1822 r.), a jeżeli byli z niższego stanu, to - doktorat. Na ogół stanowiska prałackie zajmowali duchowni wyższych święceń, chociaż były też przypadki duchownych niższych święceń. Katalog prałatów i kanoników (włocławskich) sporządził w 1915 r. ks.

\footnotetext{
${ }^{76}$ Inwentarz akt personalnych został opracowany przez siostry: Jolantę Zdrojewska i Laurencję Jędrzejczak na przestrzeni lat 50. i 60. XX w.; Librowski, Inwentarz, s. 345.

${ }^{77}$ Akta konsystorza generalnego kaliskiego, obejmujące parafie i klasztory, które przeszły w 1925 r. do diecezji częstochowskiej, zostały przekazane w 1950 r. do Częstochowy; Librowski, Inwentarz, s. 345.

${ }^{78}$ Wykaz prałatów i kanoników kruszwickich (kolegiaty św. Piotra i Pawła) opracował w maszynopisie (1938 r.) ks. Antoni Fiutak, będąc wikariuszem w Kruszwicy w latach 1932-1937, a który zginął w Dachau. Maszynopis, przekazany po zakończeniu II wojny światowej ks. Librowskiemu, liczy 133 strony i obejmuje instalacje prałatów i kanoników od 1615 r., spisy kanoników i prałatów na przestrzeni XVI-XVIII w. i wykaz prebend; Librowski, Inwentarz, s.370-371; Biblioteka kapituły włocławskiej, oprac. ks. S. Chodyński, uzup. rozdziałem o katalogach i wyd. ks. Stanisław Librowski, KDW, 43 (1949) s. 169-216, 233-280; 44 (1950) s. 33-68.
} 
S. Chodyński i wysłał do druku do Akademii Umiejętności w Krakowie. Rękopis liczący 872 strony i 900 nazwisk nie został jednak wydrukowany, ale po długim staraniu odzyskał go ks. S. Librowski dla Archiwum Diecezjalnego we Włoclawku (Teka KXIV) ${ }^{79}$.

Kapituła włocławska, będąc gospodarzem katedry, wśród swoich dokumentów zachowała inwentarz zakrystii i jej skarbca oraz akta niższych kolegiów duchowieństwa katedralnego, tj. wikariuszy, mansjonarzy i psałterzystów. Wszystkie akta wytworzone przez kapitułę, a stanowiące jeden z najważniejszych, a zarazem największych części zasobu archiwalnego w Archiwum Diecezjalnym we Włoclawku, omówił ks. S. Librowski w napisanej m.in. przez siebie monografii katedry włocławskiej, którą opracował w trzech częściach: historyczno-architektonicznej, duchowieństwo katedralne i sprawy liturgiczne. Zamieścił też 51 ilustracji. W 1952 r. opracował do użytku wewnętrznego Przewodnik po katedrze $\left(\right.$ Teka LXI) ${ }^{80}$.

Z kolei zadaniem kapituł kolegiackich była przede wszystkim troska o kult Boży. Najstarszymi kapitułami, po przeniesieniu stolicy biskupstwa do Włocławka, były: kapituła św. Wita (Teka LXX) ${ }^{81}$ i św. Piotra i Pawła w Kruszwicy (Teka LXIX) ${ }^{82}$. Pierwsza przetrwała do początku XV w.(przeniesiona do Nieszawy), a kapituła św. Piotra i Pawła uzyskała tytuł „prześwietnej” i przetrwała do czasów współczesnych (archidiecezja gnieźnieńska). Pomocą w odsłonięciu dziejów tej ostatniej służy archiwum kapituły kruszwickiej. Zgodę na zmikrofilmowanie archiwaliów kapitulnych otrzymał ks. S. Librowski od swojego kolegi obozowego ks. Leona Kijewskiego, proboszcza parafii kolegiackiej w Kruszwicy. Zawartość 31 ksiag podzielił na 9 serii. Materiał obejmował lata 1516-1843 (Teka XLVIILXXVI) ${ }^{83}$.

Krótkie stosunkowo było istnienie kapituły kolegiackiej św. Michała w Gdańsku (XII-XIII w. $)^{84}$. Z kolei ze względu na dobra w Wolborzu, posiadane od XI w. przez biskupów włocławskich, powstała tam w 1544 r. kapituła, którą zniesiono w 1819 r. Warto pamiętać, że po zmianie granic diecezji w 1818 r. na terenie nowo powstałej diecezji kujawsko-kaliskiej znalazło się aż 7 kapituł kolegiackich (w większości zniesionych po 1818 r.) z archidiecezji gnieźnieńskiej (Teka

${ }^{79}$ Librowski, Inwentarz, s. 370; tenże, Kapituła katedralna wtocławska. Zarys dziejów i organizacji, Warszawa 1949; S. Chodyński, Katalog prałatów i kanoników włocławskich, Włocławek 1914, mps; Biblioteka kapituly włocławskiej, oprac. Ks. Stanisław Chodyński, uzup. rozdziałem o katalogach i wyd. ks. Stanisław Librowski, KDW, 43 (1949) s. 169-216, 233-280; 44 (1950), s. 33 68; S. Librowski, Kwerenda Adama Naruszewicza w 1794 roku do dzieła Historia narodu polskiego w Archiwum Diecezji Włoctawskiej, Lublin 1982.

${ }^{80}$ Librowski, Inwentarz, s.366-367; tenże, Katedra Włocławska. Monografia, Włocławek 1947.

${ }^{81}$ Librowski, Inwentarz, s. 374; tenże, $Z$ dziejów katedry a nastęnnie kolegiaty św. Wita $w$ Kruszwicy, ABMK, 15 (1967) s. 251-269; W. Abraham, Statuty kapituty w Kruszwicy, „Polonia Sacra”, 8 (1956) s. 251-315.

${ }^{82}$ Librowski, Inwentarz, s.374.

83 Tamże, s.351-352, 386.

${ }^{84}$ S. Librowski, Na śladach wczesnośredniowiecznej kolegiaty i kapituły zamkowej św. Michała w Gdańsku, ABMK, 14 (1967), s.231-245 
LXVI) ${ }^{85}$. Spośród nich na szczególną uwagę zasługuje kapituła kaliska (Teka $\mathrm{LXX}^{86}$. O jej dziejach dowiadujemy się $\mathrm{z}$ archiwum kapituły kolegiackiej w Kaliszu, stanowiącym zespół średniej wielkości (zbiory sięgają 1577 r.). Podobnie średniej wielkości jest archiwum kapituły kolegiackiej Lipskich w Choczu, sięgające 1632 r. W stanie szczątkowym zachowały się: archiwum kapituły w Łasku (obejmujące akta wytworzone od 1525 r.), archiwum kapituły w Sieradzu od XVI w. i w Wolborzu (akta szczątkowe z XVIII/XIX w.). Niekompletne jest też archiwum kapituły w Uniejowie (od XVII-XIX w.). Natomiast całe archiwum kapituły wieluńskiej zostało przekazane w 1965 r. diecezji częstochowskiej (Teka XLI) ${ }^{87}$. $\mathrm{W}$ związku z różnymi zmianami związanym z reorganizacją diecezji, ks. S. Librowski dokonał cennego opisu (maszynopis) życia religijnego na przestrzeni XV-XIX w. (Teka LXII) ${ }^{88}$.

W wyniku podziału terytorialnego diecezji kujawskiej i pomorskiej w $1818 \mathrm{r}$. doszło do powstania właściwie nowej diecezji kujawsko-kaliskiej, liczącej 344 parafie; $z$ diecezji kujawskiej i pomorskiej weszły tylko cztery dekanaty: nieszawski, izbicki, brzeski i kowalski (75 parafii). Niewatpliwie łączność z dawną diecezją stanowiły: katedra, kapituła i włocławskie seminarium duchowne. Do powstałej diecezji kujawsko-kaliskiej przyłączono w 1818 r. aż 273 parafii z archidiecezji gnieźnieńskiej, 11 - z diecezji wrocławskiej, 3 - z diecezji poznańskiej oraz 1 (już w 1800 r.) z płockiej (Teka XLII) ${ }^{89}$.

Mówiąc o diecezji kujawsko-kaliskiej nie można pominąć różnego rodzaju bractw religijnych oraz cechów. Na uwagę zasługuje zwłaszcza zbiór Adama Chodyńskiego z 1875 r. pt. Przywileje, prawa i wilkury cechów i bractw rzemieślniczych oraz przemystu $i$ handlu $w$ dawnym Kaliszu. Wiadomości o tym zbiorze zamieścił w 1958 r. w Ziemi Kaliskiej ks. S. Librowski. Należy również zwrócić uwagę na zbiór, opracowany przez Adama Chodyńskiego (1878 r), pt. Dawne ustawy (administracyjne i policyjne) miasta Kalisza. Cenne jest też dzieło, opracowane przez przez Witolda Maisela, a zamieszczone w Rocznikach Kaliskich pt. Cechy jednobranżowe. Nie można też nie uwzględnić spisu, jaki nabył ks. Librowski po ks. Janie Sobczyńskim, a dotyczącym m.in. spisu cechów kaliskich (w liczbie ok. 40), szczątków akt i dokumentów tychże cechów z XVII-XVIII w. oraz odpisów przywilejów i ustaw dla niektórych z nich, np. „wieluński” z 1593-

${ }^{85}$ Librowski, Inwentarz, s. 371

${ }^{86}$ Zachował się maszynopis ks. Librowskiego dotyczący kolegiaty z kapitułami oraz kolegiami duchowieństwa, a także prepozytury parafialne archidiecezji gnieźnieńskiej do $1818 \mathrm{r}$. W składzie prałatów i kanoników kapituł kolegiackich wymienia kolegiatę Wniebowzięcia NMP (św. Józefa) w Kaliszu, Łowiczu, Kruszwicy i Łęczycy; Librowski, Inwentarz, s. 376-377

${ }^{87}$ Wszystkie kolegiaty, za wyjątkiem kaliskiej, przestały istnieć po 1818 r.; Librowski, Inwentarz, s.341-343; tenże, Statuty kapitut kolegiackich dawnej archidiecezji gnieźnieńskiej. Wstęp ogólny: Kapituły kolegiackie dawnej archidiecezji gnieźnieńskiej, ABMK, 1 (1959) z. 1, s. 167-189; tenże, z. 2: Statuty świetnej kapituły w Łowiczu, ABMK, 42 (1980) s. 345-400; 43 (1981), s. 343400; 44 (1982), s. 341-400, 46 (1983), s. 203-369; J. Szymański, Piętnaście lat badań nad dziejami polskich kapituł katedralnych i kolegiackich (1945-1960), ZN KUL, 5 (1962) nr 1, s. 91-92.

${ }^{88}$ Librowski, Inwentarz, s. 384.

${ }^{89}$ Tamże, s. 350. 
1697. Cały spis akt brackich i cechowych znajduje się w Archiwum Diecezjalnym we Włocławku oraz w Częstochowie (Teka LXXXII) ${ }^{90}$.

Z chwilą odzyskania w 1918 r. niepodległości i zawarciu przez Polskę konkordatu ze Stolicą Apostolską w 1925 r. nastąpił nowy podział terytorialny Kościoła w Polsce. $\mathrm{Z}$ części terytorium diecezji kujawsko-kaliskiej powstała wtedy diecezja częstochowska (123 parafie), a część terenu wcielono do istniejącej już od 1920 r. diecezji łódzkiej (50 parafii); parafia Duninów powróciła do diecezji płockiej (Teka XLI) ${ }^{91}$. Ponadto Stolica Apostolska przywróciła dawną nazwę diecezji: „diecezja włocławska”. Do nowej diecezji włocławskiej zostały włączone tylko dwa dekanaty z diecezji płockiej: lipnowski i mazowiecki oraz jeden dekanat kłodawski z diecezji łódzkiej. Taki stan przetrwał do 1992 r., kiedy to Jan Paweł II dokonał ponownej reorganizacji sieci metropolitalnej i diecezjalnej w Polsce, uzupełnionej w 2004 r. Do nowo powstałej w 1992 r. diecezji kaliskiej odłączono 6 dekanatów, a w uzupełniającym podziale z 2004 r. do archidiecezji gnieźnieńskiej odłączono 4 dekanaty (Teka LX) ${ }^{92}$.

Ks. S. Librowski zebrał i uporządkował organy urzędowe diecezji włocławskiej od 1907 r. oraz łódzkiej (1920 r.) i częstochowskiej (1926 r.) (Teka XLV). $\mathrm{Z}$ jego też inicjatywy s. L. Jędrzejczak dokonała spisu posiadanych czasopism diecezjalnych (Teka XLV) ${ }^{93}$.

Cały okres od 1925 r.(mimo nowego podziału) ks. S. Librowski ujął jako czwartą fazę biskupstwa włocławskiego, która posiada dwa ogólne zespoły akt Kurii Diecezjalnej Włocławskiej i Sądu Kościelnego we Włocławku. Obydwa zespoły zawierają odtworzone w 1920 r. akta, po pożarze Włocławskiej Kurii Diecezjalnej w wyniku ataku wojsk bolszewickich na Włocławek ${ }^{94}$.

W latach 1946-1950 został przez ks. S. Librowskiego uporządkowany cały

${ }^{90}$ Tamże, s. 389-390; tenże, Wiadomość o niewydajnym zbiorze Adama Chodyńskiego pt. Przywileje, prawa $i$ wilkury cechów i bractw rzemieślniczych oraz przemystu $i$ handlu $w$ dawnym Kali$s z u$, „Ziemia Kaliska”, 2 (1958) nr 4, s. 4; W. Maisel, Cechy jednobranżowe, „Rocznik Kaliski”, 8 (1975) s. 251-323.

${ }^{91}$ Ks. Librowski opracował spis parafii i duchowieństwa tej części diecezji kujawsko-kaliskiej, która weszła do diecezji częstochowskiej; Librowski, Inwentarz, s.351.

${ }^{92}$. Już w listopadzie 1918 r. ordynariusz kujawsko-kaliski biskup S. Zdzitowiecki dokonał podziału diecezji na trzy okręgi nazwane wikariatami generalnymi: włocławski, częstochowski i kaliski. Wikariuszem generalnym na całą diecezję został biskup Wojciech Owczarek, natomiast wikariuszem generalnym dla części południowej diecezji został biskup Władysław Krynicki. Oficjałem sądu biskupiego został ks. Stanisław Chodyński, a wiceoficjałami wspomniani sufragani. Oprócz sądu biskupiego we Włocławku powstały także trybunały sądowe pomocnicze w: Częstochowie (kierował bp W. Krynicki) i Kaliszu, którym kierował ks. J. Sobczyński, a który to sąd zniósł biskup K. Radoński w 1931 r. On też, najpierw w 1929 r., a następnie w 1931 r., dokonał podziału diecezji na 19 dekanatów. Kilkakrotnej korekty dekanatów dokonywali kolejni rządcy diecezji w okresie po zakończeniu II wojnie światowej. Dokładne zmiany w przynależności parafii diecezji włocławskiej do poszczególnych jej dekanatów na przestrzeni lat 1931-1952 ukazał ks. Librowski w swoim maszynopisie; Librowski, Inwentarz, s. 366

${ }^{93}$ Tamże, s. 350.

${ }^{94}$ J. Dębiński, Inwazja bolszewicka w 1920 roku na ziemi dobrzyńskiej i Kujawach wschodnich, AK, 145 (2005) s.504-505. 
zespół akt kurialnych z lat 1920-1939, które podzielił na: akta ogólne, parafialne, personalne i zakonne; zgodnie z praktyką innych diecezji, od $1953 \mathrm{r}$. zaprowadzono w aktach włocławskiej Kurii Diecezjalnej serię akt ordynariusza z własną sygnatura. Porządkując akta sądowe z lat 1920-1939 ks. S. Librowski podzielił je na sprawy (462): o wolny stan, o unieważnienie małżeństwa, o separację, o dyspensę papieską oraz sprawy różne. Nie pominął też znaczenia kronik parafialnych z lat 1901-1039 (Teka XLIII) ${ }^{95}$.

Osobny okres w historii diecezji obejmuje czas II wojny światowej. Ks. S. Librowski sytuacji Kościoła katolickiego w diecezji włocławskiej w okresie okupacji niemieckiej poświęcił swoje opracowanie, pt. Diecezja Włocławska ${ }^{96}$. Autor omówił stan ogólny diecezji przed wybuchem II wojny światowej i przejęcie 15 IX 1939 r. jej całego obszaru przez wojska niemieckie. Wskazał, że w okresie okupacji zburzono lub rozebrano 19 kościołów parafialnych, 4 kościoły pomocnicze, 3 kościoły filialne, 12 kaplic publicznych i 11 kaplic półpublicznych. Zwrócił też uwagę, że z kościołów diecezji zabrano ok. 280 dzwonów, 313 kielichów, 185 monstrancji, a zniszczeniu lub rozproszeniu uległo $90 \%$ bielizny kościelnej. Los wygnańca podzielił biskup K. Radoński, a jego sufragan biskup M. Kozal zginął w 1943 r. w Dachau. Spośród 432 kapłanów diecezji włocławskiej aresztowano 331 , a w obozach i więzieniach zginęło 224 księży, tj. 50,2\%. Liczba ta nie obejmuje wszystkich represjonowanych. Skutkiem wojny było też trwale inwalidztwo i zwiększenie zachorowalności księży ${ }^{97}$.

Autor zwrócił uwagę na działania władz kościelnych podejmowanych dla utrzymania administracji kościelnej oraz duszpasterstwa i życia religijnego, które rozróżnił, jako „duszpasterstwo polskie” oraz „duszpasterstwo niemieckie”. Nie pominął duszpasterstwa ukrytego; całkowicie swoją działalność musiało zawiesić duszpasterstwo stanowe ${ }^{98}$.

Cenne źródło stanowi też, przeprowadzona przez ks. S. Librowskiego, ankieta strat wojennych z lat 1939-1945. Zostały w niej omówione poszczególne parafie w porządku alfabetycznym i dekanatami, a także ogromne szkody poniesione nie tylko przez duchowieństwo, ale także przez włocławskich diecezjan, którzy byli wysiedlani, wywożeni na roboty i wtrącani do więzień i obozów koncentaracyjnch oraz poddawani egzekucjom, np. w Piotrkowie Kujawskim czy w Nowogrodzie. Trzeba też dodać, że w granicach diecezji włocławskiej leży Chełmno n. Nerem, w którym hitlerowcy dokonywali eksterminacji Żydów i Cyganów. Spośród ówczesnych miast diecezji najdotkliwsze starty poniósł Kalisz. Wojna spowodowała zaprzestanie działalności kościelnego szkolnictwa diecezjalnego, zakonnego, parafialnego i klasztornego (Teki: LV-LVII) ${ }^{99}$.

${ }^{95}$ Librowski, Inwentarz, s.345-347; tenże, Zachowane kroniki parafialne z terenu diecezji włoctawskiej z lat 1901-1939 oraz ich wartość jako źródta historycznego, ABMK, 18 (1969) s. 5-46.

${ }^{96}$ Tenże, Diecezja włocławska, w: Życie religijne w Polsce pod okupacja hitlerowska 19391945, red. Z. Zieliński, Warszawa 1982, s. 111-128.

${ }^{97}$ Librowski, Diecezja Włocławska, s.112-113.

${ }_{98}$ Tamże, s. 116-128.

${ }^{99}$ Librowski, Inwentarz, s.361-364; tenże, Ankieta strat wojennych (1939-1945) diecezji wtoctawskiej, ABMK, 36 (1978) s.387-404. 
Podsumowaniem niejako sytuacji i stanu Kościoła rzymskokatolickiego na terenie diecezji włocławskiej po zakończeniu II wojny światowej był wydany pod redakcją ks. S. Librowskiego Rocznik Diecezji za rok 1949, nie bez ingerencji cenzury (Teki: LVIII-LIX) ${ }^{100}$.

W historii diecezji bywało, że w celu rozwiązania niektórych kwestii, dotyczących funkcjonowaniem Kościoła, zwoływano synody, tj. zjazdy duchowieństwa pod przewodnictwem biskupa diecezjalnego. I chociaż takie synody odbywały się już w okresie kruszwickim, to jednak nie ma właściwie na ich temat żadnych wiadomości. Pierwsze źródła na temat odbywających się synodów w diecezji kujawskiej i pomorskiej pochodzą dopiero z XIII w. Przypuszcza się, że takich synodów w dalszej historii dziejów diecezji tej fazy było ok. 51. Temu zagadnieniu poświęcił swój zbiór ks. Zenon Chodyński w dziele pt. Statuta synodalia Dioecesis Vladislaviensis et Pomeraniae (Warszawa 1890 r.). Sporo uwagi temu zagadnieniu poświęcił również ks. Stanisław Chodyński, pisząc o synodach w rozprawie pt. Synody Kościoła Polskiego, a zamieszczonej w Encyklopedii Kościelnej ${ }^{101}$. Z kolei, ks. S. Librowski wspomina o synodach w związku ze zjazdami biskupów w XVIII w., jako instytucji zastępującej synody prowincjonalne. Zwraca też uwagę, na synod włocławski bp Drzewieckiego z 1756 r., o którym nie wiedział ks. Zenon Chodyński (Teka LXXX). ${ }^{102}$ Nie było żadnego synodu w okresie istnienia diecezji kujawsko-kaliskiej. Dopiero pierwszy taki synod miał miejsce w latach 1966-1967, a ostatni zwołany w 1977 r., jednak przerwany na skutek śmierci biskupa J. Zręby w 1986 r., został wznowiony w 1992 r. i zakończony w 1994 roku ${ }^{103}$.

Synody prowincjonalne, a także diecezjalne nakazywały zakładanie szkół parafialnych, a przy klasztorach szkół klasztornych. Na istnienie takich szkół wskazują protokoły wizytacji diecezji kujawskiej i pomorskiej (Teka LXII) ${ }^{104}$. W okresie zaborów miejsce szkół parafialnych zajęły szkoły elementarne, prowadzone przez państwo i wyjęte spod kurateli Kościoła. Oprócz szkół parafialnych i klasztornych istniała też szkoła katedralna we Włocławku, której zadaniem było przede wszystkim kształcenie kandydatów przygotowujących się do kapłaństwa. ${ }^{105} \mathrm{Ze}$ szkołą katedralną we Włocławku związane są tradycje kopernikowskie Włocław-

${ }^{100}$ Rocznik Diecezji Włocławskiej 1949. Pierwszy od roku 1939, redaktor Archiwariusz Diecezjalny [ks. Librowski], Włocławek 1949, s. 355.

${ }^{101}$ S. Chodyński, Synody Kościoła Polskiego, w: „Encyklopedia Kościelna”, t. 27, Warszawa 1904, s. 394-419.

${ }^{102}$ Librowski, Inwentarz, s. 388-389; tenże, Sprawa rzekomych synodów diecezji włocławskiej po 1641 roku, ABMK, 2 (1961) z. 1/2, s. 345-352; tenże, Konferencje biskupów w XVIII wieku jako instytucja zastępujaca synody prowincjonalne. Cz. 1: Obrady w sprawach Kościoła i szczqtkowa po nich dokumentacja, ABMK, 47 (1983) s.239-311; tamże, Cz. 2: Obrady w sprawach Państwa i zachowana po nich dokumentacja, ABMK, 48 (1984) s. 181-357.

${ }^{103}$ S. Librowski, Synody diecezji włoctawskiej, KDW, 50 (1967) s. 82-94; J. Grężlikowski, Recepcja reformy trydenckiej $w$ diecezji włocławskiej $w$ świetle ustawodawstwa synodalnego, Włocławek 2000.

${ }^{104}$ S. Librowski, Inwentarz, s. 384.

${ }^{105}$ S. Chodyński, Szkoła katedralna włocławska, Włocławek 1900. 
ka. Osobie Kopernika, jego pomnikom i tablicom poświęcił swój wykład ks. Librowski w czasie akademii urządzonej ku uczczeniu wielkiego astronoma w Seminarium Duchownym we Włocławku 18 III 1973 r.(Teka LXX) ${ }^{106}$.

W XVI w., po soborze trydenckim, funkcję szkoły katedralnej przejęły powstałe seminaria duchowne. Pierwsze seminarium założył na synodzie diecezjalnym we Włocławku w 1568 r. biskup S. Karnkowski. Erekcja seminarium prawdopodobnie miała miejsce 16 VIII 1569 r. Początkowo kształciło się w nim 24 alumnów, w tym ośmiu, znających język niemiecki, z przeznaczeniem dla pomorskiej części diecezji. Ze względu na obszerny archidiakonat pomorski i zamieszkujący ten teren duży procent ludności mówiącej w języku niemieckim, powstała myśl, za czasów biskupa Hieronima Rozrażewskiego (1684 r.), aby stworzyć w Szotlandzie k. Gdańska specjalne seminarium, prowadzone przez jezuitów, w którym kształciliby się przyszli duchowni znający dobrze język polski i niemiecki. Takie seminarium powstało w 1621 r., jednak protestanci spalili gmach i mimo późniejszych prób nie doszło do właściwego jego funkcjonowania. Z kolei biskup Maciej Łubieński podjął się założenia dla duchowieństwa niemieckiego seminarium w Kamieniu Krajeńskim i Chojnicach (Teka LXXI) ${ }^{107}$. Różnego rodzaju trudności w prowadzeniu seminarium (XVI-XVII w.) sprawiły, że alumni przebywali w różnych szkołach. Biskup Paweł Wołucki, by przywrócić właściwe funkcjonowanie seminarium, w 1619 r. wystawił nowy gmach seminaryjny we Włocławku, w którym zgromadził wszystkich kleryków swojej diecezji. Jednak wojny szwedzkie, jak zresztą cały XVII w., zahamowały rozwój włocławskiego seminarium. Nie pomogły też zabiegi biskupa B. Madalińskiego (ok 1685 r.), aby seminarium oddać w zarząd księży komunistów, zwanych bartoszkami. Dopiero odnowienia seminarium dokonał biskup Felicjan Szaniawski, który 31 XII 1719 r. oddał zarząd seminarium w ręce księży misjonarzy św. Wincentego a Paulo i którzy prowadzili je do1864 r., tj. do kasaty wszystkich zakonów w Królestwie Polskim. Wtedy na ich miejsce przyszli księża diecezjalni i taki stan trwa do dnia dzisiejszego. W tym miejscu warto wspomnieć, że pewne, wprawdzie bezskuteczne, próby przeniesienia seminarium z Włocławka do Lądu n. Wartą, podjął po 1818 r. biskup J. Koźmian, a w 1839 r. biskup W. Tomaszewski (ze względu na asystę) umieścił szkołę (kandydaci do seminarium) w zabudowaniach pobernardyńskich w Kaliszu, która po jego śmierci przestała jednak istnieć (Teka LXXI, LXXXI $)^{108}$.

Ks. Stanisław Chodyński ukazał historię seminarium duchownego w monografii pt. Seminarium Włocławskie z 1904 r., oraz w rozprawie pt. Seminaria duchowne w Polsce zamieszczonej w Encyklopedii Kościelnej w 1902 r. (Teka LXXXI). Ks. Librowski wskazał dokumenty dotyczące seminariów w Polsce, m.

${ }^{106}$ Ks. Librowski zamierzał wraz z ks. K. Rulką wydać dzieło ku czci Kopernika złożone z trzech części (zachował się maszynopis planu wydania takiego dzieła); Librowski, Inwentarz, s. 374.

${ }^{107}$ Tamże, s. 380

${ }^{108}$ Tamże, s. 379-380, 389; Librowski, Dekret Soboru Trydenckiego o seminariach i pierwsze seminaria diecezjalne $w$ Polsce, AK, 72 (1969) s. 237-258; tenże, Włocławskie Seminarium Duchowne na przestrzeni czterech stuleci, KDW, 52 (1969) s. 176-188. 
in. seminarium kieleckiego z 1727 r., trzy dokumenty z XVIII w. dotyczące fundacji seminarium w Tykocinie oraz statut Wyższego Seminarium Duchownego we Włocławku z 1960 r. (Teka LXXXI) ${ }^{109}$.

Nie można zapominać, że w historii diecezji biskupi (m. in. Wojciech Gniewosz w 1759 r.) wielokrotnie podejmowali próby utworzenia specjalnej szkoły dla przyszłych alumnów wyższego seminarium, czyli coś w rodzaju niższego seminarium. Wspomniany biskup Wojciech Gniewosz planował nawet zniesienie konwentu kanoników regularnych w Lubrańcu, by w tych pomieszczeniach utworzyć taką szkołę. Starania biskupa nie uzyskały jednak pozytywnego skutku. Udało się to dopiero biskupowi S. Zdzitowieckiemu, który w 1908 r. powołał do istnienia szkołę, nazwaną później Liceum Piusa X. Ten sam biskup powołał teżw 1916 r. szkołę średnią im. Jana Długosza. Ostatecznie w latach 1916-1951 funkcjonowało we Włocławku gimnazjum $\mathrm{i}$ liceum prowadzone przez siostry urszulanki $\mathrm{i}^{110}$.

$Z$ włocławskim seminarium duchownym ściśle związana jest Biblioteka im. Księży Chodyńskich. Swoje biblioteki mieli także: biskupi, kapituły, kolegiaty, klasztory i parafie ${ }^{111}$. Ks. S. Librowski podjął zamiar opracowania katalogów rękopisów i druków bibliotek kościelnych. On też opracował i wydał drukiem katalogi biblioteki kapituły włocławskiej z lat 1590-1827. Szczególnie cenny jest, pochodzący z 1590 r., Cathalogus librorum Ecclesiae Cathedralis Vlasislawiensis in Libraria Capitulari. Na uwagę zasługuje również katalog książek kolegiaty kaliskiej z ok. 1604 r., czy kolegiaty uniejowskiej i kanoników regularnych laterańskich z Lubrańca z 1818 r. Z parafialnych bibliotek (XVII-XIX w.) na uwage zasługuje, licząca 791 dzieł, biblioteka w Koniecpolu (Teka LXXVIII) ${ }^{112}$.

Obchody jubileuszu 400 -lecia istnienia włocławskiego seminarium duchownego zbiegły się z 50. rocznicą założenia Katolickiego Uniwersytetu Lubelskiego, którego jednym $z$ inicjatorów był wykładowca włocławskiego seminarium duchownego, ks. Idzi Radziszewski. Z tej okazji ks. S. Librowski 19 XII 1968 r. wygłosił we Włocławku referat pt. Diecezja i Seminarium Włocławskie a Katolicki Uniwersytet Lubelski. Wskazał m. in. istotny udział włocławian w założeniu uczelni, uwzględnił postawę biskupa S. Zdzitowieckiego wobec uniwersytetu oraz wymienił wszystkich pracowników naukowych pracujących na KUL-u, a pochodzących z diecezji włocławskiej oraz innych pracowników tej uczelni delego-

${ }^{109}$ Librowski, Inwentarz, s. 389; S. Chodyński, Seminarium Włocławskie, Włocławek 1904 ; tenże, Seminaria duchowne w Polsce, „Encyklopedia Kościelna”, t. 25, Warszawa 1902, s. 34-89

${ }^{110}$ A. Mietz, M. Pawlak, M. Szczotkowska-Topić, Gimnazjum i Liceum im ks. Jana Dlugosza we Włocławku 1916-1951, Bydgoszcz 1995; M. Pawlak, Gimnazjum i liceum sióstr urszulanek we Włocławku w latach 1916-1951, w: Dawne włocławskie gimnazja (w latach 1876-1939), Bydgoszcz 1998, s. 33-43; J. Dębiński, O katechizacji w diecezji włocławskiej w II Rzeczpospolitej, „Pedagogia Christiana", 1(15)/2005, s.163-183.

${ }^{111}$ S. Chodyński, Szkoła oo. Reformatów w Włocławku, Włocławek 1911.

${ }^{112}$ Librowski, Inwentarz, s. 387-388; tenże, Ocalate i pomnażane pomoce ewidencyjno-inwentaryzacyjne archiwum, biblioteki, skarbca i zakrystii katedry włoctawskiej z lat 1516-1983, ABMK, 52 (1986) s. 57-155; tenże, Katalog ksiażek kolegiaty kaliskiej z ok. 1604 r., w: Repertorium akt wizytacyjnych, t. 28, ABMK, 28 (1974) s. 109; L. Grzebień, Biblioteka biskupa Hieronima Rozrażewskiego (1542-1600), t. 22, Lublin 1971, s. 61-168. 
wanych przez władzę diecezjalną. Wymienił też wszystkich księży, którzy studiowali na KUL w latach 1918-1939 oraz w latach 1954-1958 (Teka LXXI) ${ }^{113}$.

W historii diecezji zawsze ważną rolę odgrywały zakony i klasztory. W chwili powstania diecezji kruszwickiej, a potem włocławskiej dominującym zakonem byli benedyktyni. Osiedlili się w XI w. w Kruszwicy (do nich należała katedra św. Piotra i Pawła) oraz we Włocławku (kościół św. Jana, 1065-1315). Oni też opiekowali się przytułkiem i kościołem św. Gotarda w Szpetalu (XI-XIII w.). Po nich duszpasterstwo do połowy XIV w. przejęli cystersi; swoje placówki mieli też w: Oliwie, Pelplinie i Koronowie. $\mathrm{Z}$ innych zakonów należy wymienić: dominikanów, karmelitów i brygidki w Gdańsku, reformatów w Stolcembergu i Wejherowie, norbertanki w Żukowie, benedyktynki w Żarnowcu, kartuzów w Kartuzach i bernardynów w Nowem. W archidiakonacie kruszwickim wśród zakonów należy wymienić: norbertanki w Strzelnie, reformatów w Gniewkowie, Inowrocławiu i Łabiszynie, jezuitów, karmelitów i bernardynów w Bydgoszczy oraz cystersów w Koronowie. $Z$ kolei w archidiakonacie włocławskim należy wymienić w końcu XVIII w. zakony: dominikanów w Brześciu Kujawskim, kanoników regularnych w Lubrańcu, reformatów we Włocławku, franciszkanów konwentualnych w Radziejowie i Nieszawie, paulinów w Brdowie oraz karmelitów w Zakrzewie. Po zmianie granic diecezji w 1818 r. na terenie nowej diecezji kujawsko-kaliskiej znalazł się Kazimierz Biskupi, w którym był klasztor benedyktynów z Międzyrzecza oraz kamedułów w Biniszewie. W granicach diecezji znalazło się też narodowe sanktuarium w Częstochowie. Drugim wielkim sanktuarium były Gidle k. Częstochowy oraz sanktuarium św. Józefa w Kaliszu ze słynnym obrazem Świętej Rodziny, ukoronowanym w 1796 r. Temu ostatniemu oraz innym kościołom i klasztorom kaliskim wiele uwagi poświęcił w swojej pracy badawczej ks. Librowski. Szczególne znaczenie dla niego miały odpisy prac dokonanych przez ks. Jana Sobczyńskiego, proboszcza parafii św. Mikołaja w Kaliszu czy odpisy prac Adama Chodyńskiego o kościele i klasztorze kanoników regularnych przy kościele św. Mikołaja (Teka LXII) ${ }^{114}$. Na cenne źródła do historii regionu kaliskiego, zwłaszcza kościół św. Wojciecha w Kaliszu ( pojezuicki), który przymusowo został przekazany protestantom (1798 r.), a odzyskany dla diecezji włocławskiej w 1945 r. zwrócił uwagę ks. S. Librowski w swoim maszynopisie z 1960 r. (Teka LXII) ${ }^{115}$. Duże znaczenie mają tu wypisy i odpisy do Kalisza i okolicy, które wykonał ks. J. Sobczyński, a nabył z drugiej ręki w 1952 r. ks. S. Librowski. Zawartość rękopisów dotyczy akt metrykalnych, wizytacyjnych, kopie dokumentów cechowych, żywoty prałatów i kanoników gnieźnieńskich z dzieła ks. Jana Korytkowskiego oraz odpisy $\mathrm{z}$ Liber Beneficiorum Laskiego (Teki: LXXVIILXXVIII) ${ }^{116}$. W tym miejscu warto pamiętać, że w granicach obecnej diecezji włocławskiej znajduje się sanktuarium w Licheniu. Jest też kilka ukoronowanych

${ }^{113}$ Librowski, Inwentarz, s. 378-379; tenże, Chronologiczna bibliografia odnotowana ks. Stanisława Librowskiego z lat 1939-1983, ABMK, 47 (1983) s.24.

${ }^{114}$ Librowski, Inwentarz, s. 367-368; tenże, Kronika kościelna Kalisza [z lat] 1901-1938 i jej autor, KDW, 53 (1959) s. 88-96.

${ }^{115}$ Librowski, Inwentarz, s. 383.

${ }^{116}$ Tamże, s. 386-387 
obrazów, m. in w: Charłupi Małej (1937 r.), Brdowie (1983 r.) i Ostrowąsie (1986 r.), czy też miejsc z obrazami słynącymi łaskami, jak: Bieniszew, k. Konina, Błenna k. Izbicy Kuj., Galew, k. Turku oraz Uniejów i Dobrów k. Koła, gdzie czczony jest błogosławiony Bogumił (Teka LXII) $)^{117}$.

$\mathrm{Z}$ diecezją włocławską związany jest też kult świętych i błogosławionych. W tym temacie należy wskazać Pięciu Braci Męczenników z Kazimierza Biskupiego, którzy ponieśli śmierć męczeńską w 1003 r. Z kolei z kultem błogosławionego Bogumiła, zatwierdzonym przez Stolicę Apostolską w 1925 r., związany jest Uniejów i Dobrów k. Koła ${ }^{118}$. Z parafii Uniejów pochodził sługa Boży biskup Wojciech Owczarek ${ }^{119}$. Patronem Zduńskiej Woli jest św. Maksymilian Maria Kolbe (ur.1894 r.) ${ }^{120}$. Z diecezją włocławską związane jest także życie błogosławionego biskupa Michała Kozala, zamordowanego w 1943 r. w obozie koncentracyjnym w Dachau, a wyniesionego na ołtarze w 1987 r., i który od 1995 r. jest patronem Włocławka ${ }^{121}$. Postulatorem $\mathrm{w}$ procesie beatyfikacyjnym był $\mathrm{m}$. in. ks. S. Librowski (Teka XVI) ${ }^{122}$. Spośród 108 męczenników wyniesionych na ołtarze w 1999 r. przez papieża Jana Pawła II jest 7 księży i dwóch alumnów z diecezji włocławskiej (ostatnią świętą wyniesioną na ołtarze przez Jana Pawła II w 2000 r. a pochodzącą z parafii Świnice Warckie była św. Faustyna Kowalska) ${ }^{123}$. Ks. S. Librowski w swej notatce zawarł wykaz imion świętych, którzy byli związani z die-

117 Tamże, s. 383

${ }^{118}$ L. Jędrzejczak, Dzieło jego trwa. Stuga Boży biskup Wojciech Owczarek, Włocławek 1997.

119 S. Librowski, Stuga Boży biskup Wojciech Stanisław Owczarek(1893-1938) i jego dzieło. (Referat wygłoszony we Włocławku 1 X 1988 r. na pięćdziesięciolecie jego śmierci $i$ w dniu rozpoczęcia procesu beatyfikacyjnego), ABMK, 57 (1988) s.323-329. tenże, Przedmowa [do pracy s. Marii Laurencji Jedrzejczak, Wojciech Stanisław Owczarek, biskup tyt. Askaloński, sufragan włocławski, założyciel Zgromadzenia Sióstr Wspólnej Pracy od Niepokalanej Maryi], ABMK, 54 (1987) s. 155-156; tenże, Człowiek ośmiu błogosławieństw [przedmowa], w: Dzieło jego trwa, s. 5-7;tenże, Biskup Wojciech Owczarek. Pisma i listy duchowne, z.1: Muszę zostać świętym!(Postanowienia rekolekcyjne), ABMK, 40 (1980) s. 203-288.

120 Błogosławiony Maksymilian Maria Kolbe, błogosławiony diecezjanin, KDW, 56 (1972) s.101-1054.

${ }^{121}$ S. Librowski, Kozal Michat, w: Hagiografia polska. Słownik bio-bibliograficzny, t. 1, Poznań 1971, s. 849-863; tenże, Kozal Michat (1893-1943) - biskup sufragan włocławski, więzień obozu koncentracyjnego w Dachau, w: PSB, t. 14, Wrocław 1968-1969, s. 601-602; tenże, Źródła do biografii biskupa Michała Kozala, AK 55 (1957) s. 289-294; tenże[ ks. postulator], Życiorys stugi Bożego [biskupa Michała Kozala], KDW, 54 (1960) s. 368; W. Frątczak, Michat Kozal, w: Nasi święci, Poznań 1995, s. 427-436.

${ }^{122}$ S. Librowski, Inwentarz, s. 146-206; tenże, Poszerzona baza źródłowa do biografii błogosławionego Michała Kozala biskupa i męczennika(1893-1943). Odcinek pierwszy, ABMK 57(1988) s. 313-321; tenże, Kwestionariusz wypetniony dotyczqcy życia, działalności, prześladowań, śmierci $i$ cnót stugi Bożego biskupa Michała Kozala (1983-1943), rozesłany w 1960 roku przez postulatora jego beatyfikacji, Opracowat $i$ wydat Stanisław Librowski b. postulator, ABMK, 57 (1988) s. 273312; tenże, Wypowiedzi współczesnych o księdzu i biskupie Michale Kozalu (1893-19430. Z własnych tek postulatora oprac. $i$ wyd. Stanisław Librowski, towarzysz więzienny i obozowy, ABMK, 56 (1988) s. 311-381.

${ }^{123}$ Męczennicy za wiarę. Studzy Boży z diecezji włocławskiej, oprac. T. Kaczmarek, Włocławek 1998; I. Borkiewicz, Faustyna Helena Kowalska, w: Nasi święci, Poznań 1995, s. 163-174. 
cezję włocławską. Nie pominął też legend: lubstowskiej i skulskiej z czasów gnieźnieńskich oraz raciążskiej z okresu włocławskiego (Teka LXII) ${ }^{124}$.

Włocławek, stolica biskupstwa, jest od początku XX w. prężnym ośrodkiem teologicznym. To z grona wykładowców włocławskiego seminarium duchownego wyszedł założyciel KUL-u, ks. Idzi Radziszewski i wielki Prymas Tysiąclecia, kard. Stefan Wyszyński. Już w 1909 r. zaczęło ukazywać się czasopismo naukowe Ateneum Kapłańskie, a pod koniec XX w. także Wtoctawskie Studia Teologiczne. Od 1907 r. wydawano Kronikę Diecezji Kujawsko-Kaliskiej, która była urzędowym organem diecezji kujawsko-kaliskiej, a którą w latach 20.XX w. przemianowano na Kronike Diecezji Włocławskiej, a obecnie na Miesięcznik Diecezji Włoctawskiej-Kronika. Po zakończeniu II wojny światowej w diecezji wydawany był z przerwami tygodnik (w pewnym okresie dwutygodnik) Ład Boży; obecnie ukazuje się wspólnie z ogólnopolskim tygodnikiem katolickim Przewodnik Katolicki. To w Ładzie Bożym ks. S. Librowski w latach 1947-1948 zamieścił 97 biogramów księży, którzy zginęli w okresie II wojny światowej ${ }^{125}$.

Ks. S. Librowski, odkrywając dzieje diecezji włocławskiej, zamierzał napisać jej dwutomową monografię. Przedstawił nawet skrócony plan takiej pracy. Jej dzieje wiązał z Kołobrzegiem. Dlatego też zawsze twierdził z Kołobrzegu - przez Kruszwice do Włocławka (Teka LX) ${ }^{126}$.

\section{DIE DIÖZESE BRESLAU UND IHRE GESCHICHTE IN DEN „MAPPEN” VON PROF. STANISŁAW LIBROWSKI}

\section{Zusammenfassung}

Die Diözese Wrocław (Breslau) gehört mit zu den ältesten in Polen. Ihre Geschichte ist mit der Existenz des Bistums in Kołobrzeg (Kolberg, Pommerscher Teil) und danach in Kruszwica (Kruschwitz) und Włocławek (Leslau) verbunden. Ihre interessante und zugleich komplizierte Vergangenheit wurde von P. Prof. Stanisław Librowski (1914-2002) erforscht, der Lehrberauftragter am Höheren Priesterseminar in Włocławek, Professor der Katholischen Universität Lublin, der Akademie für Katholische Theologie (ATK) in Warschau und der Humanistisch-Ökonomischen Hochschule in Włocławek, langjähriger Direktor des Diözesanarchivs in Włocławek sowie Gründer und Redakteur der Zeitschrift „Archiwa, Biblioteki i Muzea Kościelne” (ABMK) war. Während seiner langjährigen Arbeit trug er viel historisches Material zusammen, das er in entsprechende Abteilungen gliederte (die sogenannten „Librowski-Mappen”.

${ }^{124}$ Librowski, Inwentarz, s. 384.

${ }^{125}$ S. Librowski, Ofiary zbrodni niemieckiej (diecezja włocławska), „Ład Boży”, 14-52 (1947) oraz 1-9 (1948).

${ }^{126}$. Librowski, Inwentarz, s. 366; tenże, Z Kołobrzegu-przez Kruszwicę-do Włocławka, Włocławek 1946. tenże, Zarys historii diecezji włocławskiej, Włocławek 1952-1953, s.37,mps. 
Pater S. Librowski bezeichnete die gesammelten Dokumente als „handschriftliches Erbe", aber in Wirklichkeit handelt es sich um gedruckte Materialien, Kopien alter Dokumente, Exzerpte aus Archivalien, in der Gegenwart erstellte Dokumente, Verzeichnisse von Dokumenten und verschiedenen Sammlungen, Pläne und Skizzen für Arbeiten und sogar kleinere von ihm selbst verfasste Abhandlungen, eine technische und mechanische Dokumentation und sogar Zeitungsausschnitte.

Viele der in diesen Mappen gesammelten Dokumente betreffen die Geschichte der Breslauer Diözese. Besondere Aufmerksamkeit verdient das 1947 von Pater S. Librowski erstellte Verzeichnis eigenständiger Originaldokumente aus dem 12. und 13. Jahrhundert, die die Diözese Kujawien und Pommern betreffen. Er verwies auch auf die Existenz einer beträchtlichen Zahl von die Diözese Kujawien und Pommern betreffenden Dokumenten, die sich in anderen Archiven befinden, zum Beispiel in Pelplin, Danzig, Krakau oder Warschau. Ein wertvolles Quellenverzeichnis zur Geschichte des Diözese Włocławek bildet das in den Kopienbüchern enthaltene Inventarverzeichnis von Dokumenten aus dem 14.18. Jahrhundert.

Ein wichtiges Unternehmen zur Aufdeckung der Geschichte der Diözese Włocławek in ihrer ältesten Phase stellte auch die Veröffentlichung der Inedita bis 1475 durch P. Librowski dar, die 13 die Jahre 1300-1400 betreffenden Dokumente, 38 Dokumente aus der ersten Hälfte des 15. Jahrhunderts sowie 31 aus der zweiten Hälfte des 15. Jahrhunderts umfassten. Material zur Geschichte lieferte auch das Ensemble bischöflicher Akten, die in drei Serien gegliedert wurden: Wirtschaftsakten, Akten zur Tätigkeit (kurz „Akten” genannt) und Visitationsakten. Besondere Aufmerksamkeit verdienen die von P. Librowski angefertigten Abschriften bischöflicher Akten aus dem 17.-18. Jahrhundert (Fundations-, Erektions-, Inkorporations-, Organisations-, Administrations und Visitationsdokumente).

Pater S. Librowski verwies bei der Besprechung der Geschichte der Diözese in der Zeit der Polnischen Teilungen auf die wichtige Rolle der Konsistorien, von denen das in Kalisz (1887) das erste und das in Włocławek (das kujawische) das zweite Generalkonsistorium bildete, während sich in Piotrków Trybunalski (Petrikau) das Foralkonsistorium befand (seit 1918 in Częstochowa). Er unterstrich auch die Rolle der Kapitel, die sich mit eigenen Statuten regierten und eine eigene Dokumentation verfertigten. Alle Akten des Domkapitels behandelte er in der von ihm verfassten monographischen Arbeit über den Dom zu Włocławek.

Viele der in den „Mappen” von Pater Librowski enthaltenen Materialien betreffen die Visitationen der Diözese in ihrer kujawischen und pommerschen Phase. Und den gesamten Zeitraum ab 1925 gliederte er in zwei Gruppen: die Akten der Diözesankurie von Włocławek und die Akten des Kirchengerichts in Włocławek. Darüber hinaus dokumentierte er sorgfältig die Verluste der Diözese in der Zeit des 2. Weltkrieges.

Als Pater Librowski die Geschichte der Diözese Włocławek immer besser erforscht hatte, beabsichtigte er eine zweibändige Monographie zu schreiben. Aber immer unterstrich er, das die Geschichte der Diözese Włocławek „,von Kołobrzeg über Kruszwica nach Włocławek führt”. 